\title{
Review
}

\section{Curcumin: A Challenge in Cancer Treatment}

\section{Purusotam Basnet * and Natasa Skalko-Basnet}

Drug Transport and Delivery Research Group, Department of Pharmacy, University of Troms $\varnothing$, Tromsø, N-9037, Norway

\begin{abstract}
Oxidative damage initiates the inflammation and inflammation has been pointed out as the root cause of cancer and various other chronic diseases such as diabetes, hypertension, Alzheimer's disease, etc. Epidemiological and clinical studies have suggested that cancer could be prevented or significantly reduced by appropriate treatment with anti-oxidant and anti-inflammatory drugs. Therefore, curcumin, a principal component of turmeric (curry spice) exhibiting strong anti-oxidant and anti-inflammatory activities, might be a potential candidate for the prevention and/or treatment of cancer and other chronic diseases. However, curcumin, in spite of its excellent safety profile, multitargeting effects and strong evidences on the molecular levels, could not achieve the desired therapeutic outcome in the past clinical trials, mainly due to its low solubility and poor bioavailability. Curcumin can be developed as a therapeutic drug through improvement in formulation properties or delivery systems, enabling its enhanced absorption and cellular uptake. This review mainly focuses on its anti-oxidant and anti-inflammatory potentials and recent developments in dosage form and delivery systems, opening the possibilities of therapeutic application of curcumin in the prevention and/or treatment of cancer.
\end{abstract}

Keywords: curcumin; cancer; anti-oxidant; anti-inflammatory; drug delivery

\section{Background}

Human life is a result of collective effort and function of approx. up to 13 trillions of cells. The average life span of each cell is estimated as of about three months. Therefore the death rate up to 130 billions cells per day can be expressed mathematically and they are replaced by the new cells each day under normal body physiology and function. However, because of environmental influences and genetic instabilities some of the cells gain the power of immortality and initiates to the development of cancer (malignant neoplasm) which leads to the development of tumour microenvironment. Cancer is the second leading cause for mortality in US and many European countries [1,2]. Based on the origin of tumour, almost $90 \%$ of cancer arise from the epithelial sheet of tissues in the body called 'carcinoma' such as the cancer of skin, breast, lungs, colon, etc., approximate $2 \%$ of cancers are 'sarcomas' which arise in muscles, bone, cartilage, fibrous tissues, etc. The other types of cancers such as 'leukaemia' and 'lymphoma' are originated from blood forming cells and from cells of the immune systems, respectively. [1]

The hallmarks of cancer comprise six biological capabilities such as 1) sustaining proliferative signalling, 2) evading growth suppressors, 3) resisting cell death, 4) enabling replicate mortality, 5) inducing angiogenesis and 6) activating metastasis during the multistep development of human tumours [3]. Genome instability and immune guided inflammatory reactions lead to the development of tumour microenvironment. In the last three decades, the introduction of mechanism-based targeted therapies to treat human cancers provided better understanding of cancer pathogenesis. Therefore a selected therapeutic target should have effects on tumour promoting inflammation, enabling replicate immortality, activating invasion and metastasis, inducing anti-angiogenesis, genome instability and mutation, resisting cell death, deregulating cellular energy, sustaining proliferative signalling, evading growth suppressor and avoiding immune destruction [3]. In response to the therapy, cancer cells may also reduce their original dependence on a particular capability, becoming more dependent on another

*Author of correspondence: E-Mail: purusotam.basnet@uit.no Tel.: +47-7764-6160; Fax: +47-7764-6151 
hallmark; this representing a quite different form of acquired drug resistance. This concept is exemplified by recent discoveries [4-6]. Therefore, a multi-targeted molecule might be better choice for the treatment of cancer. Recent lines of studies pointed out that the plant polyphenols such as curcumin, catechins, resveratrols etc. are targeted candidates for the prevention and/or treatment of cancer because of their multitargeted biological activities. In this review, we are exploring the possibility of prevention and/or treatment of cancer with curcumin.

In fact, curcumin, a principal component in turmeric, is a traditionally used anti-inflammatory agent. The scientific literature in the last 20 years on curcumin showed that curcumin might be a desirable candidate in the prevention and/or treatment of cancer. Current literature (according to the SciFinder database, August 23, 2011) showed a total of 12,903 hits on "curcumin". Among them, 60 references were of clinical trials, 1,094 references in a form of review and 1,515 references on patent applications. In the same database, the numbers of references during 1990 to 2000 were 1463, 7, 106, and 118 for total, clinical trials, reviews, and patent applications, respectively, and there were only a total number of 600 references on curcumin recorded from 1950 to 1989. At the time of writing this review, a total of 56 clinical trials (phase I and phase II) on curcumin are listed on the website of the US A National Institutes of Health [7]. Among them, 16 trials were already completed, three were terminated, one was withdrawn and the rest of the studies are on-going [Table 1]. Such a vast number of researches on curcumin mainly targeting its therapeutic applications can be expected to bring an interesting outcome in the near future.

Table 1. List of clinical trials on curcumin.

\begin{tabular}{|c|c|c|c|}
\hline Title & Recruitment & Conditions & Interventions/Analysis \\
\hline $\begin{array}{l}\text { Effect of supplemental oral curcumin in patients } \\
\text { with atopic asthma }\end{array}$ & Completed & Atopic asthma & $\begin{array}{l}\text { Dietary supplement: } \\
\text { Curcumin/ Other }\end{array}$ \\
\hline $\begin{array}{l}\text { Study investigating the ability of plant exosomes } \\
\text { to deliver curcumin to normal and colon cancer } \\
\text { tissue }\end{array}$ & Recruiting & Colon cancer & $\begin{array}{l}\text { Dietary supplement: } \\
\text { Curcumin conjugated with } \\
\text { plant exosomes/ Other: No } \\
\text { intervention }\end{array}$ \\
\hline Oral curcumin for radiation dermatitis & Recruiting & $\begin{array}{l}\text { Radiation-induced } \\
\text { dermatitis }\end{array}$ & Drug: Curcumin \\
\hline $\begin{array}{l}\text { Use of curcumin for treatment of intestinal } \\
\text { adenomas in familial adenomatous polyposis } \\
\text { (FAP) }\end{array}$ & Recruiting & $\begin{array}{l}\text { Lower tract/ upper } \\
\text { tract polyps in } \\
\text { patients with FAP }\end{array}$ & $\begin{array}{l}\text { Drug: Calcumin } \\
\text { (Curcumin)/ Others: Risk } \\
\text { factor questionnaire/ Blood } \\
\text { samples/ Biopsies } \\
\text { (Sigmoidoscopy)/ Biopsies } \\
\text { (Upper endoscopy) }\end{array}$ \\
\hline $\begin{array}{l}\text { Curcumin therapy in patients with impaired } \\
\text { glucose tolerance and insulin resistance }\end{array}$ & Recruiting & $\begin{array}{l}\text { Type } 2 \text { diabetes/ pre- } \\
\text { diabetes/ insulin } \\
\text { resistance/Cardiovasc } \\
\text { ular risk }\end{array}$ & Drug: Curcumin \\
\hline $\begin{array}{l}\text { Curcumin (turmeric) in the treatment of irritable } \\
\text { bowel syndrome: a randomized-controlled trial }\end{array}$ & Recruiting & $\begin{array}{l}\text { Irritable bowel } \\
\text { syndrome }\end{array}$ & $\begin{array}{l}\text { Dietary supplement: } \\
\text { Curcumin/ Placebo }\end{array}$ \\
\hline $\begin{array}{l}\text { Curcumin in preventing colon cancer in smokers } \\
\text { with aberrant crypt foci }\end{array}$ & $\begin{array}{ll}\text { Active, } \\
\text { recruiting }\end{array}$ & $\begin{array}{l}\text { Colorectal cancer/ } \\
\text { Pre-cancerous } \\
\text { condition/ Tobacco } \\
\text { use disorder }\end{array}$ & $\begin{array}{l}\text { Dietary supplement: } \\
\text { Curcumin }\end{array}$ \\
\hline $\begin{array}{l}\text { Curcumin (diferuloylmethane derivative) with or } \\
\text { without bioperine in patients with multiple } \\
\text { myeloma }\end{array}$ & Completed & Multiple myeloma & $\begin{array}{l}\text { Drug: } \\
\text { Bioperine }\end{array}$ \\
\hline $\begin{array}{l}\text { Efficacy and safety of curcumin formulation in } \\
\text { Alzheimer's disease }\end{array}$ & Recruiting & Alzheimer's disease & $\begin{array}{ll}\text { Dietary } & \text { supplement: } \\
\text { Curcumin } & \text { formulation/ } \\
\text { Placebo } & \end{array}$ \\
\hline
\end{tabular}




\begin{tabular}{|c|c|c|c|}
\hline $\begin{array}{l}\text { Pharmacokinetics of curcumin in healthy } \\
\text { volunteers }\end{array}$ & Completed & Healthy & Drug: Curcumin \\
\hline $\begin{array}{l}\text { Curcumin in preventing colorectal cancer in } \\
\text { patients undergoing colorectal endoscopy or } \\
\text { colorectal surgery }\end{array}$ & Recruiting & Colorectal cancer & $\begin{array}{lr}\text { Dietary } & \text { supplement: } \\
\text { Curcumin/ } & \text { Other: HPLC/ } \\
\text { Laboratory } & \text { biomarker } \\
\text { analysis/ } & \text { Pharmacological } \\
\text { study/ } & \text { Procedure: } \\
\text { Diagnostic } & \text { endoscopic } \\
\text { procedure/ } & \text { Therapeutic } \\
\text { conventional surgery }\end{array}$ \\
\hline Curcumin biomarkers & $\begin{array}{l}\text { Enrolling by } \\
\text { invitation }\end{array}$ & Colorectal cancer & $\begin{array}{l}\text { Dietary supplement: } \\
\text { Curcumin C3 tablet }\end{array}$ \\
\hline Curcumin pharmacokinetics & Recruiting & $\begin{array}{l}\text { Comparative } \\
\text { multidose } \\
\text { pharmacokinetics }\end{array}$ & $\begin{array}{l}\text { Dietary supplement: } \\
\text { Curcumin }\end{array}$ \\
\hline $\begin{array}{l}\text { The effects of oral curcumin on heme oxygenase- } \\
1 \text { (ho-1) in healthy male subjects }\end{array}$ & Completed & Healthy & $\begin{array}{l}\text { Dietary supplement: } \\
\text { Curcumin }\end{array}$ \\
\hline $\begin{array}{l}\text { Curcumin in treating dermatitis caused by } \\
\text { radiation therapy in patients with breast cancer }\end{array}$ & $\begin{array}{ll}\text { Not } & \text { yet } \\
\text { recruiting }\end{array}$ & Breast cancer & $\begin{array}{l}\text { Dietary supplement: } \\
\text { curcumin/ Other: placebo }\end{array}$ \\
\hline Curcumin for type 2 diabetic patients & Recruiting & $\begin{array}{l}\text { Type } 2 \text { Diabetes } \\
\text { mellitus/ } \\
\text { Cardiovascular } \\
\text { abnormalities }\end{array}$ & Drug: Curcumin \\
\hline Study of nano-curcumin and resveratrol & $\begin{array}{ll}\text { Not } & \text { yet } \\
\text { recruiting }\end{array}$ & Advanced cancer & $\begin{array}{l}\text { Dietary supplement: Nano- } \\
\text { curcumin/ Resveratro1/ } \\
\text { Nano-curcumin MTD }\end{array}$ \\
\hline $\begin{array}{l}\text { A pilot study of curcumin and ginkgo for treating } \\
\text { Alzheimer's disease }\end{array}$ & Completed & Alzheimer's disease & $\begin{array}{l}\text { Drug: Placebo and ginkgo } \\
\text { extract/ Curcumin and } \\
\text { ginkgo extract/ Curcumin } \\
\text { and ginkgo extract }\end{array}$ \\
\hline $\begin{array}{l}\text { Curcumin in pediatric inflammatory bowel } \\
\text { disease }\end{array}$ & Completed & $\begin{array}{l}\text { Inflammatory } \\
\text { Bowel disease/ } \\
\text { Ulcerative colitis/ } \\
\text { Crohn's disease }\end{array}$ & Drug: Curcumin \\
\hline $\begin{array}{l}\text { Trial on safety and pharmacokinetics of } \\
\text { intravaginal curcumin }\end{array}$ & $\begin{array}{ll}\text { Not } & \text { yet } \\
\text { recruiting }\end{array}$ & $\begin{array}{ll}\text { Uterine } & \text { cervical } \\
\text { dysplasia } & \end{array}$ & Drug: Curcumin \\
\hline $\begin{array}{l}\text { Trial of curcumin in cutaneous T-cell lymphoma } \\
\text { patients }\end{array}$ & $\begin{array}{ll}\text { Not } & \text { yet } \\
\text { recruiting }\end{array}$ & $\begin{array}{ll}\text { Cutaneous } & \text { T-cell } \\
\text { lymphoma } & \end{array}$ & $\begin{array}{l}\text { Dietary supplement: } \\
\text { Curcumin (Turmeric) }\end{array}$ \\
\hline $\begin{array}{l}\text { Curcumin for prevention of oral mucositis in } \\
\text { children chemotherapy }\end{array}$ & Recruiting & $\begin{array}{l}\text { Chemotherapy } \\
\text { induced mucositis }\end{array}$ & $\begin{array}{lr}\text { Other: } & \text { Mouth wash/ } \\
\text { Dietary } & \text { supplement: } \\
\text { Curcumol } & \end{array}$ \\
\hline $\begin{array}{l}\text { A randomized, double-blind, placebo-controlled } \\
\text { trial of curcumin in leber's hereditary optic } \\
\text { neuropathy (lhon) }\end{array}$ & Recruiting & $\begin{array}{l}\text { Optic atrophy, } \\
\text { hereditary, leber }\end{array}$ & Drug: Curcumin \\
\hline $\begin{array}{l}\text { Curcumin with pre-operative capecitabine and } \\
\text { radiation therapy followed by surgery for rectal } \\
\text { cancer }\end{array}$ & $\begin{array}{ll}\text { Active, } & \text { not } \\
\text { recruiting } & \end{array}$ & Rectal cancer & $\begin{array}{l}\text { Drug: Curcumin/ Placebo/ } \\
\text { Radiation: Radiotherapy/ } \\
\text { Drug: Capecitabine }\end{array}$ \\
\hline $\begin{array}{l}\text { Curcumin biomarker trial in head and neck } \\
\text { cancer }\end{array}$ & Recruiting & $\begin{array}{l}\text { Head and neck } \\
\text { cancer }\end{array}$ & $\begin{array}{lr}\text { Dietary } & \text { supplement: } \\
\text { Microgranular } & \text { curcumin } \\
\text { C3 complex® } & \end{array}$ \\
\hline Trial of curcumin in advanced pancreatic cancer & $\begin{array}{l}\text { Active, } \\
\text { recruiting }\end{array}$ & $\begin{array}{l}\text { Pancreatic } \\
\text { neoplasms/ }\end{array}$ & Drug: Curcumin \\
\hline
\end{tabular}




\begin{tabular}{|c|c|c|c|}
\hline & & Adenocarcinoma & \\
\hline $\begin{array}{l}\text { Pilot study of curcumin formulation and } \\
\text { ashwagandha extract in advanced osteosarcoma }\end{array}$ & Recruiting & Osteosarcoma & $\begin{array}{l}\text { Dietary supplement: } \\
\text { Curcumin powder/ } \\
\text { Ashwagandha extract }\end{array}$ \\
\hline $\begin{array}{l}\text { Early intervention in mild cognitive impairment } \\
\text { (mci) with curcumin }+ \text { bioperine }\end{array}$ & $\begin{array}{ll}\text { Active, } & \text { not } \\
\text { recruiting } & \end{array}$ & $\begin{array}{l}\text { Mild cognitive } \\
\text { impairment/ Mild } \\
\text { Alzheimer's disease }\end{array}$ & $\begin{array}{l}\text { Dietary supplement: } \\
\text { Curcumin + bioperine }\end{array}$ \\
\hline Bio-availability of a new liquid turmeric extract & $\begin{array}{ll}\text { Not } & \text { yet } \\
\text { recruiting }\end{array}$ & Healthy & $\begin{array}{l}\text { Drug: Liquid turmeric/ } \\
\text { Curcumin extract }\end{array}$ \\
\hline $\begin{array}{l}\text { Curcumin for the prevention of radiation-induced } \\
\text { dermatitis in breast cancer patients }\end{array}$ & $\begin{array}{l}\text { Active, not } \\
\text { recruiting }\end{array}$ & Breast cancer & $\begin{array}{l}\text { Drug: } \\
\text { complex/ Placebo }\end{array}$ \\
\hline Curcumin in rheumatoid arthritis & Recruiting & Rheumatoid arthritis & $\begin{array}{ll}\begin{array}{l}\text { Drug: } \\
\text { (Longvida }^{\mathrm{TM}} \text { ) }\end{array} & \text { Curcumin } \\
\end{array}$ \\
\hline $\begin{array}{l}\text { Curcumin }+ \text { aminosalicylic acid (5ASA) versus } \\
\text { 5asa alone in the treatment of mild to moderate } \\
\text { ulcerative colitis }\end{array}$ & $\begin{array}{ll}\text { Not } & \text { yet } \\
\text { recruiting }\end{array}$ & Ulcerative colitis & $\begin{array}{l}\text { Dietary supplement: } \\
\text { Curcumin/ Drug: 5- } \\
\text { Aminosalicylic acid }\end{array}$ \\
\hline $\begin{array}{l}\text { Curcumin in patients with mild to moderate } \\
\text { Alzheimer's disease }\end{array}$ & Completed & Alzheimer's disease & $\begin{array}{l}\text { Dietary supplement: } \\
\text { Curcumin C3 complex }\end{array}$ \\
\hline $\begin{array}{l}\text { Effect of curcumin as nutraceutical in patients of } \\
\text { depression }\end{array}$ & Completed & $\begin{array}{l}\text { Major depressive } \\
\text { disorder }\end{array}$ & $\begin{array}{lr}\text { Dietary } & \text { supplement: } \\
\text { Curcumin/ } & \text { Drug: } \\
\text { Fluoxetine/ } & \end{array}$ \\
\hline $\begin{array}{l}\text { Curcumin to prevent complications after elective } \\
\text { abdominal aortic aneurysm (AAA) repair }\end{array}$ & $\begin{array}{ll}\text { Not } & \text { yet } \\
\text { recruiting }\end{array}$ & $\begin{array}{l}\text { Acute kidney } \\
\text { injury/Abdominal } \\
\text { aortic aneurysm }\end{array}$ & $\begin{array}{l}\text { Drug: Curcumin/ Other: } \\
\text { placebo }\end{array}$ \\
\hline Gemcitabine with curcumin for pancreatic cancer & Completed & Pancreatic cancer & $\begin{array}{l}\text { Drug: Curcumin } \quad(+ \\
\text { gemcitabine) }\end{array}$ \\
\hline $\begin{array}{l}\text { Physiological effects of new polyphenol-enriched } \\
\text { foods in humans }\end{array}$ & Recruiting & Healthy & $\begin{array}{l}\text { Dietary supplement: Free } \\
\text { curcumin/ Encapsulated } \\
\text { curcumin/ encapsulated } \\
\text { curcumin plus piperine/ } \\
\text { Free cocoa polyphenol/ } \\
\text { Encapsulated r cocoa } \\
\text { polyphenols/ Control nut } \\
\text { cream }\end{array}$ \\
\hline $\begin{array}{l}\text { The efficacy of coenzyme q10 and curcumin in } \\
\text { patients with myelodysplastic syndromes }\end{array}$ & Withdrawn & $\begin{array}{l}\text { Myelodysplastic } \\
\text { syndrome }\end{array}$ & $\begin{array}{l}\text { Drug: } \quad \text { Curcumin; } \\
\text { Coenzyme q10 }\end{array}$ \\
\hline $\begin{array}{l}\text { Curcumin for treatment of intestinal adenomas in } \\
\text { familial adenomatous polyposis (FAP) }\end{array}$ & Recruiting & $\begin{array}{l}\text { Familial } \\
\text { adenomatous } \\
\text { polyposis }\end{array}$ & $\begin{array}{l}\text { Dietary supplement: } \\
\text { Curcumin/ Placebo }\end{array}$ \\
\hline $\begin{array}{l}\text { Phase III trial of gemcitabine, curcumin and } \\
\text { celebrex in patients with metastatic colon cancer }\end{array}$ & $\begin{array}{ll}\text { Not } & \text { yet } \\
\text { recruiting } & \end{array}$ & Colon neoplasm & Drug: Celecoxib/Curcumin \\
\hline $\begin{array}{l}\text { Use of curcumin in the lower gastrointestinal } \\
\text { tract in familial adenomatous polyposis patients }\end{array}$ & Terminated & $\begin{array}{l}\text { Familial } \\
\text { adenomatous } \\
\text { polyposis }\end{array}$ & Drug: Curcumin \\
\hline $\begin{array}{l}\text { Efficacy of nf-kb inhibition for reducing } \\
\text { symptoms during maintenance therapy in } \\
\text { multiple myeloma patients }\end{array}$ & $\begin{array}{ll}\text { Not } & \text { yet } \\
\text { recruiting }\end{array}$ & Multiple myeloma & Drug: Curcumin/Placebo \\
\hline $\begin{array}{l}\text { The effect of coltect (selenium, curcumin and } \\
\text { green tea) on irritable bowel syndrome }\end{array}$ & $\begin{array}{ll}\text { Not } & \text { yet } \\
\text { recruiting }\end{array}$ & $\begin{array}{l}\text { Irritable } \quad \text { bowel } \\
\text { syndrome }\end{array}$ & $\begin{array}{l}\text { Dietary supplement: } \\
\text { coltect/ Placebo }\end{array}$ \\
\hline $\begin{array}{l}\text { Phase III trial of gemcitabine, curcumin and } \\
\text { celebrex in patients with advance or inoperable } \\
\text { pancreatic cancer }\end{array}$ & Recruiting & Pancreatic cancer & $\begin{array}{l}\text { Drug: } \quad \text { Gemcitabine/ } \\
\text { Curcumin/ Celebrex }\end{array}$ \\
\hline Curcumin for the prevention of colon cancer & Completed & Colorectal cancer & $\begin{array}{l}\text { Dietary } \\
\text { Curcumin }\end{array}$ \\
\hline
\end{tabular}




\begin{tabular}{|c|c|c|c|}
\hline $\begin{array}{l}\text { Reducing symptom burden - non small cell lung } \\
\text { cancer (NSCLC) }\end{array}$ & $\begin{array}{ll}\text { Not } & \text { yet } \\
\text { recruiting } & \end{array}$ & $\begin{array}{l}\text { Non small cell lung } \\
\text { cancer }\end{array}$ & $\begin{array}{lr}\text { Drug: } & \text { Armodafinil/ } \\
\text { Bupropion/ } & \text { Minocycline/ } \\
\text { Curcumin/ } & \text { Behavioral: } \\
\text { Telephone questionnaire }\end{array}$ \\
\hline Symptom burden in head and neck cancer & $\begin{array}{ll}\text { Not } & \text { yet } \\
\text { recruiting }\end{array}$ & $\begin{array}{l}\text { Head and neck } \\
\text { cancer }\end{array}$ & $\begin{array}{l}\text { Other: Placebo/ Drugs: } \\
\text { Curcumin/ Armodafinil/ } \\
\text { Minocycline/ Bupropion }\end{array}$ \\
\hline $\begin{array}{l}\text { The effects of curcuminoids on aberrant crypt } \\
\text { foci in the human colon }\end{array}$ & Terminated & Aberrant crypt foci & Drug: Sulindac/ curcumin \\
\hline $\begin{array}{l}\text { A nutritional supplement capsule containing } \\
\text { curcumin, green tea extract, polygonum } \\
\text { cuspidatum extract, and soybean extract in } \\
\text { healthy participants }\end{array}$ & Completed & $\begin{array}{l}\text { Healthy, no } \\
\text { evidence of disease }\end{array}$ & 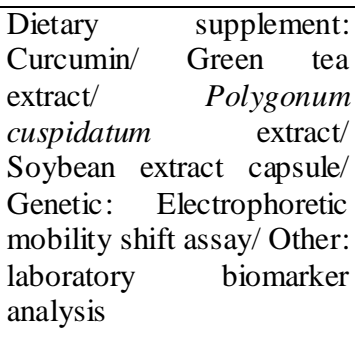 \\
\hline $\begin{array}{l}\text { The efficacy and safety of Curcuma domestica } \\
\text { extracts and ibuprofen in knee osteoarthritis }\end{array}$ & Recruiting & Osteoarthritis & $\begin{array}{l}\text { Drug: Curcuma domestica } \\
\text { extracts/ Ibuprofen }\end{array}$ \\
\hline $\begin{array}{l}\text { Safety and preliminary efficacy of the treatment } \\
\text { of kidney allograft with curcumin-containing } \\
\text { preservation solution }\end{array}$ & Recruiting & $\begin{array}{ll}\text { End stage } & \text { renal } \\
\text { failure with } & \text { renal } \\
\text { transplant } & \end{array}$ & $\begin{array}{l}\text { Device: CDC solution/ } \\
\text { UW-solution }\end{array}$ \\
\hline $\begin{array}{l}\text { The efficacy and tolerability of coltect as add-on } \\
\text { in patients with active ulcerative colitis - an open } \\
\text { label }\end{array}$ & Recruiting & Ulcerative colitis & $\begin{array}{l}\text { Dietary supplement: } \\
\text { Coltect }\end{array}$ \\
\hline $\begin{array}{l}\text { Sulindac and plant compounds in preventing } \\
\text { colon cancer }\end{array}$ & Terminated & Colorectal cancer & $\begin{array}{l}\text { Dietary supplement: } \\
\text { Curcumin/ Rutin/ Drug: } \\
\text { Quercetin/ Sulindac }\end{array}$ \\
\hline $\begin{array}{l}\text { Curcumin for the chemoprevention of colorectal } \\
\text { cancer }\end{array}$ & $\begin{array}{l}\text { Active, not } \\
\text { recruiting }\end{array}$ & $\begin{array}{l}\text { Adenomatous } \\
\text { polyps }\end{array}$ & Drug: Curcuminoids \\
\hline $\begin{array}{l}\text { Effects of curcumin on postprandial blood } \\
\text { glucose, and insulin in healthy subjects }\end{array}$ & Completed & Diabetes & \\
\hline $\begin{array}{l}\text { Curcuminoids for the treatment of chronic } \\
\text { psoriasis vulgaris }\end{array}$ & Completed & Psoriasis & $\begin{array}{l}\text { Drug: Curcuminoids } \mathrm{C} 3 \\
\text { complex } \AA\end{array}$ \\
\hline $\begin{array}{l}\text { A clinical study of curcuminoids in the treatment } \\
\text { of oral lichen planus }\end{array}$ & Completed & Oral lichen planus & Curcuminoids/ \\
\hline $\begin{array}{l}\text { Safety study of orally administered curcuminoids } \\
\text { in adult subjects with cystic fibrosis }\end{array}$ & Completed & Cystic fibrosis & $\begin{array}{l}\text { Drug: } \quad \text { Standardized } \\
\text { turmeric extract }\end{array}$ \\
\hline Effects of nutraperf consumption in runners & Completed & Nutrition processes & $\begin{array}{l}\text { Dietary supplement: } \\
\text { Carbohydrate drink }\end{array}$ \\
\hline
\end{tabular}

The table was prepared from the information given in Ref. [6].

Our particular interest is focused on the anti-oxidative and anti-inflammatory properties of curcumin, which might provide a therapeutic window for the prevention and/or treatment of cancer. Curcumin down regulates various pro-inflammatory cytokine expressions such as tumor necrosis factor (TNF- $\alpha$ ), interleukins (IL-1, IL-2, IL-6, IL-8, IL-12) and chemokines, most likely through inactivation of the nuclear transcription factor, nuclear factor (NF)- $\kappa$ B. Likewise, curcumin is known to decrease the inflammation associated with experimental colitis, including a substantial reduction of the rise in myleoperoxidase (MPO) activity, an established marker for inflammatory cells (mainly polymorphonuclear leukocytes) and TNF- $\alpha[8,9]$. In addition, curcumin is able to reduce colonic nitrite 
levels and down regulate cyclooxygenase (COX)-2, inducible nitric oxide synthase ( $i \mathrm{NOS}$ ) expression and p38 mitogen activated protein kinase (MAPK) activation [8,9]. In spite of the abundant evidence at the molecular level, and extensive studies at the preclinical and clinical levels, its therapeutic outcome remains a challenge owing to its low solubility and poor bioavailability [10]. Therefore, this review focuses particularly on the recent developments in dosage forms and novel delivery systems for curcumin for the treatment of cancer.

\section{Inflammation and Cancer}

The functional relation between inflammation and cancer was hypothesized by Virchow already in 1863 [11]. Recent researches have expanded the concept that inflammation is a critical component of tumor progression. Many cancers arise from the site of inflammation, chronic irritation and infection. It should be noted that acute inflammation process is the essential part of the body physiology for the prevention from pathogens. In contrast, a low level chronic inflammation that can persist over 20 to 30 years is pathogenic, eventually leading to cancer as well as other chronic diseases (Figure 1). Proinflammatory factors might be external such as environmental pollutants (cigarette smoke, vehicle fuels), viruses (HTLV1, HPV, HCV, HBV, EBV), bacteria (Helicobacter pylori), food (grilled, fried, red meat), stress (chemical, physical, psychological), etc. [12]. One of these external pro-inflammatory factors or in combination together induce pro-inflammatory molecules such as reactive oxygen species $\left(\mathrm{O}_{2}{ }^{--}, \mathrm{OH}^{-} \mathrm{NO}\right.$, $\left.\mathrm{ONOO}^{-}{ }^{-}\right)$, cytokines (TNF- $\alpha$, IL-1 $\beta$, IFN- $\gamma$, IL-6. IL-8, IL-12, IL-18), together with other vital molecules NF- $\kappa \mathrm{B}$, $i \mathrm{NOS}, \mathrm{COX}-2$, 5-LOX, MMP-9. Several immune cells and their products guide and connect the inflammation reaction to the cancer progression [13-15].

Reactive oxygen species (ROS) initiate oxidative stress and oxidative damage in the pathophysiology of many chronic inflammatory and degenerative disorders. The responsible ROS are mainly superoxide anion $\left(\mathrm{O}_{2}^{-}\right)$, hydroxyl $\left(\mathrm{OH}^{-}\right)$and nitric oxide $\left(\mathrm{NO}^{\circ}\right)$ radicals along with non-free radical species such as hydrogen peroxide $\left(\mathrm{H}_{2} \mathrm{O}_{2}\right)$ and nitrous acid $\left(\mathrm{HNO}_{2}\right)$ [16]. The chronic generation of ROS (particularly such as $\mathrm{O}_{2}^{--}, \mathrm{OH} \mathrm{NO}^{\circ}, \mathrm{ONOO}^{-}$) leads to lipid peroxidation of cellular membranes, altered balance of anti-oxidant enzymes, such as an increase in cellular glutathione levels (GSH) and stress-induced activation of activator protein-1 (AP-1), play pivotal roles in the development of pathophysiology and degenerative disorders [17]. Another modulator, $\mathrm{NO}^{\circ}$, a short-lived, lipophilic molecule, generated from L-arginine by various NADPH-dependent enzymes called NO synthases (NOSs) play vital role in inducing cascades of pro-inflammatory molecules together with the physiologic functions such as vasodilatation, inhibition of platelet aggregation, neurotransmission, immune defence, and intracellular signalling [18]. NO is classified as a free radical species and some of its intermediates can damage DNA directly or interfere with DNA repair via protein damage $[19,20]$. Whereas high doses of NO (millimolar) seem to be cytotoxic and induce apoptosis, lower doses of NO (micro molar) can protect malignant cells from apoptosis in vitro through up regulation of COX-2 [21-23]. In addition, endothelial heme oxygenase-1 (HO-1) induced by cellular stress plays a critical role in defending the body against oxidant-induced injury during inflammatory processes [24].

Anti-oxidant enzymes such as superoxide dismutase (SOD), catalase (CAT) and glutathione peroxidase (GPX), together with the nonenzymatic system such as glutathione and vitamins (A, C, and E) defend against over-reaction of free radicals [25]. In addition to this, other molecules like polyphenols, ubiquinol-10, glucose and albumin, as well as minerals, such as selenium and zinc, can also counteract free radical activity. These insights are fostering a new anti-oxidants and antiinflammatory therapeutic approach to the cancer treatment. By the use of aspirin, a non-steroidal antiinflammatory drug (NSAID), colon cancer risk is reduced by $40 \%-50 \%$ by COX-2 inhibition mechanism [26-28]. Another NSAID, flurbiprofen, showed efficacy in inhibiting colon carcinogenesis due to its strong anti-metastatic effect together with the COX enzymes inhibition. Besides NSAIDs, the inhibitors of TNF- $\alpha$, a highly studied pro-inflammatory cytokines and immune cells modulator, have also been targeted as the way of treatment for various cancers in the current clinical trails [29]. Therefore, anti-inflammatory drugs might open additional therapeutic option for the treatment of cancers and other chronic diseases. 


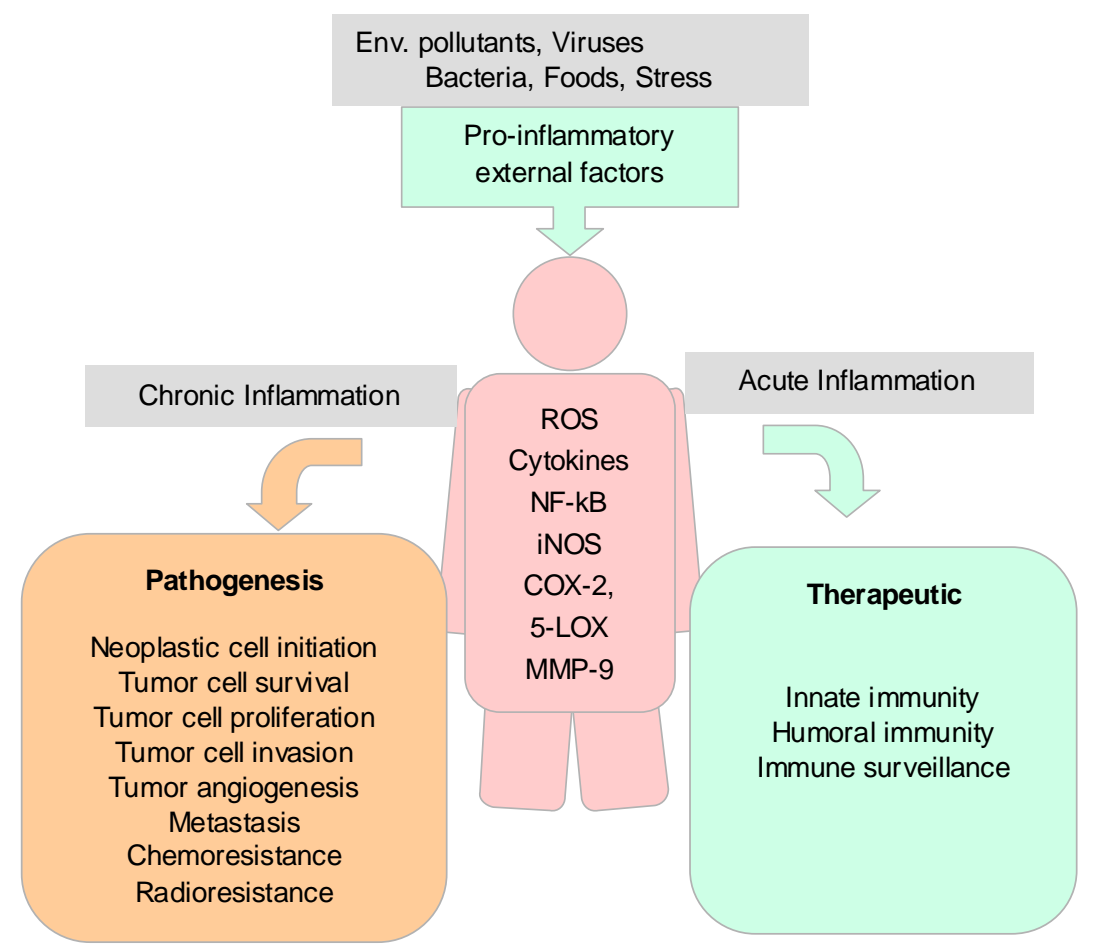

Figure 1. Chart showing external and internal pro-inflammatory factors and some of their biological responses.

\footnotetext{
Environmental pollutants (cigarette smoke, vehicle fuels); Viruses (HTLV1, HPV, HCV, HBV, EBV); Bacteria (Helicobacter pylori); Food (grilled, fried, red meat); Stress (chemical, physical, psychological), ROS: reactive oxygen species $\left(\mathrm{O}_{2}{ }^{--}, \mathrm{OH}^{-}\right.$, NO; ONOO--); Cytokines (TNF- $\alpha$, IL-1 $\beta$, IFN- $\gamma$, IL-6, IL-8, IL-12, IL-18). Although these pro-inflammatory molecules are essential for normal cell regulation processes having therapeutic value, uncontrolled and too high exposure to such molecules can lead to cancer and other chronic diseases.
}

In this context, in the last two decades, curcumin has been extensively studied as a potent anti-oxidant and anti-inflammatory agents due to its ability to scavenge directly the ROS and by down regulating proinflammatory cytokines and transcription factors, respectively. Additionally, data provided interesting insight into the immunomodulatory potential of curcumin. It can modulate the activation of T-cells, Bcells, macrophages, neutrophils, natural killer (NK) cells, and dendritic cells. Nevertheless, curcumin, at low doses, can also enhance antibody responses [30]. These molecular evidences suggest that its reported favourable effects in cancers might be due to direct anti-oxidative and anti-inflammatory effects, as well in part to its ability to modulate the immune systems.

\section{Turmeric (curry spice) and Curcumin Chemistry}

Turmeric is well known curry spice obtained by grinding dried rhizomes mainly from Curcuma longa L. (Zingiberaceae). Among several synonyms 76 names are listed in the WHO monograph [31]. Some important names are Haldi (in Hindi), Haridra or Gauri (in Sanskrit), Chiang Huang (in Chinese), Ukon (in Japanese), Kurkum (in Arabic), Besar (in Nepali), etc.

Curcuma longa is cultivated throughout the tropical climates in Indian subcontinent. It is a perennial herb, which grows to up to $1 \mathrm{~m}$. It has curved, oblong, and ovate leaves with beautiful white to colourful flowers and cylindrical rhizomes (Figure 2). India produces most of the World's supply of turmeric [32,33]. Recently, it has been used by the food industry as additive, flavouring, preservative, and colouring agent (e.g., in mustard, margarine, soft drinks, and beverages). As a safe colouring agent, curcumin is listed in the international numbering system for food additives with the code E100. Non-medical applications of turmeric include cosmetics, particularly "Sindur (an alkaline turmeric)" keeps very important rituals meaning in Hindu ceremonies. Commercially available turmeric may contain essential oils, polyphenols, protein, fat, minerals, carbohydrates, and moisture. The aromatic properties of turmeric are thought to be attributable to its volatile essential oils [34]. 


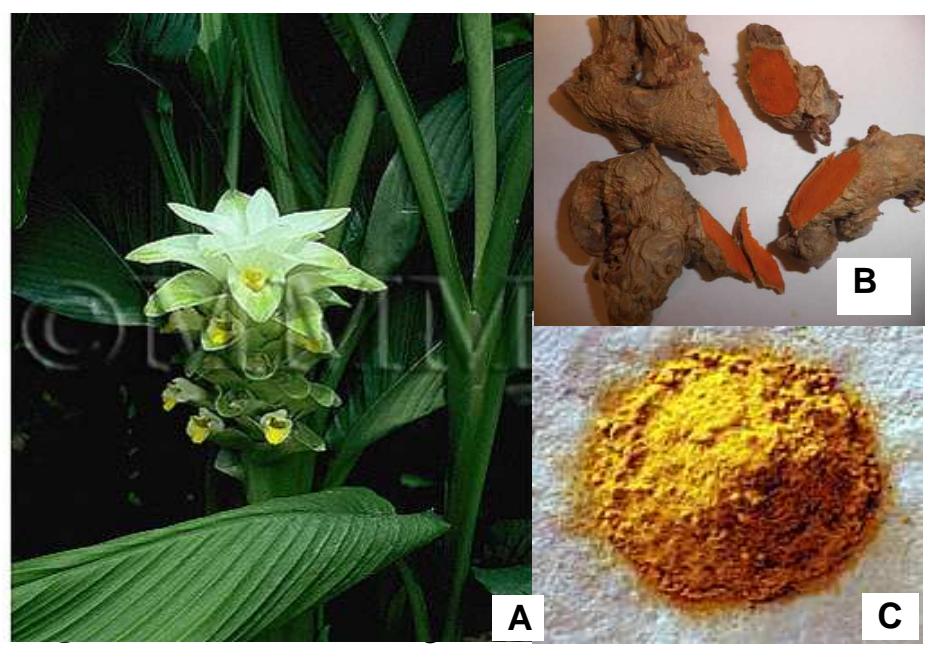

A. Curcuma longa Linn. Plant with flower; B. Freshly cut rhizome and C. Turmeric powder (dried and powdered rhizome). Picture A was taken with the permission of the Museum of Materia Medica, Toyama, Japan.

The yellow colour of turmeric is mainly due to the presence of polyphenolic curcuminoids, which constitute approx. 3-5\% of most turmeric preparations. The alcoholic extract of turmeric mainly contains three curcuminoids, namely curcumin (also referred as curcumin I or diferuloylmethane), desmethoxycurcumin (curcumin II), and bisdesmethoxycurcumin (curcumin III) (Figure 3). Curcumin was purified first by Vogel and Pelletier in 1815 and its structure as diferuloylmethane was established in 1910 [35,36]. Its chemical structure was confirmed in 1973 by Roughley and Whiting with NMR technique [37] and the solution structure was confirmed only in 2007 by Payton et al. [38].<smiles>COc1cc(/C=C/C(=O)CC(=O)/C=C/c2ccc(O)c(OC)c2)ccc1O</smiles><smiles>O=C(/C=C/c1ccc(O)cc1)CC(=O)/C=C/c1ccc(O)cc1</smiles>

Bisdemethoxy curcumin (Curcumin III)

Figure 3. Structure of three major curcuminoids in turmeric.

It should be noted that most commercially available "curcumin" is not a pure curcumin, but rather is a mixture of curcumin (approx. 77\%), desmethoxycurcumin (approx. 18\%) and bisdesmethoxycurcumin (approx. 5\%) [39]. Curcuminoids are also reported from C. aromatica, $C$. phaecaulis, $C$. zedoaria, C. xanthorrhiza, C. mangga among the more than 120 Curcuma plants identified so far. Among the curcuminoids, curcumin is the main and biologically targeted phytochemical and $C$. longa is the main source of curcumin [30].

Curcumin [chemical name: $E, E$-1,7-bis(4-hydroxy-3-methoxyphenyl)-1,6-heptadiene-3,5 dione] is a bis- $\alpha, \beta$-unsaturated $\beta$-diketone. It has a molecular weight as 368.38 , a melting point as $179-183{ }^{\circ} \mathrm{C}$, 
and molecular formula as $\mathrm{C}_{21} \mathrm{H}_{20} \mathrm{O}_{6}$. Under physiological conditions, curcumin can exist in both a bisketo and an en-ol form, which coexist in equilibrium (Figure 4).<smiles>C=CCOc1cc(/C=C/C2=[O+]COC(/C=C/c3ccc(O)c(OC)c3)=C2)ccc1OC</smiles>

Figure 4. Keto- and enol- tautomeric form of curcumin.

Curcumin is readily soluble in dimethylsulfoxide (DMSO), ethanol or acetone, but it is sparingly soluble in water. In acidic and neutral solutions as well as in the solid state, the keto form of curcumin predominates, and acts as a potent donor of $\mathrm{H}$-atoms. In contrast, under alkaline conditions $(\geq \mathrm{pH} 8)$, the enolic form predominates, and the phenolic part of the molecule plays the principal role as an electron donor [40]. Curcumin is found to be relatively stable in presence of calf serum or human blood comparing to basic buffer solution [41]. Addition of antioxidants (ascorbic acid, $\mathrm{N}$ acetylcysteine or glutathione) to culture media also inhibited the degradation of curcumin [42]. At alkaline $\mathrm{pH}$, yellow curcumin changes to dark red colour. Under physiological conditions, the $\lambda_{\max }$ for curcumin is observed at $420 \mathrm{~nm}$.

\section{Curcumin Safety and Toxicity}

Turmeric (curcumin) is taken in a small daily dose as a spice by the mass population in many Asian countries. In one survey, in terms of its dietary use in Nepal, turmeric consumption was found to be up to $1.5 \mathrm{~g}$ per person per day, equivalent to approx. $50 \mathrm{mg}$ of curcumin/day [43]. In India, where the average intake of turmeric is reported as high as $2.0-2.5 \mathrm{~g}$ per day (corresponding to approx. up to 0.1 $\mathrm{g}$ of curcumin), no toxicities or adverse effects have been reported or studied at the population level [44]. However the doses given in clinical studies are expected to be rather higher than those normally consumed in the diet. This fact underlines the need for systematic safety and toxicity studies. Based on repeated studies, turmeric is Generally Recognized As Safe (GRAS) by the US FDA, and curcumin has been granted an acceptable daily intake level of $0.1-3 \mathrm{mg} / \mathrm{kg}$-bw by the Joint Expert Committee of the Food and Agriculture Organization/World Health Organization (FAO/WHO) [45].

The systematic studies conducted in rats, dogs, or monkeys with the support of the Prevention Division of the US National Cancer Institute (NCI), the oral doses of curcumin up to $3.5 \mathrm{~g} / \mathrm{kg}$-bw did not show adverse effects for up to 90 days [45]. In a preclinical study involving the administration of $2 \%$ dietary curcumin (approx. $1.2 \mathrm{~g} / \mathrm{kg}$-bw) to rats for 14 days [46] or in a study of $0.2 \%$ dietary curcumin (approx. $0.3 \mathrm{~g} / \mathrm{kg}$-bw) administered to mice for 14 weeks, no toxicity was observed [47]. Furthermore, a reproductive toxicity study with the oral curcumin administration of up to $1.0 \mathrm{~g} / \mathrm{kg}$-bw daily, no toxicity was observed in two successive generations in rats [48].

In a study performed in India, daily administration of $1.2-2.1 \mathrm{~g}$ of oral curcumin to patients with rheumatoid arthritis for 2-6 weeks did not cause any toxicity [49]. Cheng et al. in Taiwan studied oral $0.5,1.0,2.0,4.0$, and $8.0 \mathrm{~g}$ of curcumin daily for three months to patients with preinvasive malignant or high risk premalignant conditions and no noticeable adverse effects were detected [50]. Lao et al. studied safety of curcumin in healthy volunteers using curcumin capsules (containing $75 \%$ curcumin, $23 \%$ demethoxycurcumin and $2 \%$ bisdemethoxycurcumin) with single escalating doses from 0.5 to 12.0 g. Among 24 enrolled healthy subjects, seven developed adverse effects, including diarrhea, headaches, rashes and yellowish stools. All toxicities observed were of grade 1 and not related to the doses. In this study, the maximum tolerated dose could not be determined because more than $12.0 \mathrm{~g}$ of curcumin is regarded as too bulky [51]. 
In a phase I clinical trial on oral curcumin in patients with advanced colorectal cancer in which the US $\mathrm{NCI}$ criteria were used to assess potential toxicity, curcumin was well tolerated at all dose levels up to $3.6 \mathrm{~g}$ daily for up to four months [52]. Adverse effects related to curcumin consumption reported by patients in these studies were mainly gastrointestinal (nausea and diarrhoea). Two abnormalities were detected in blood tests in this trial, both possibly related to treatment: an increase in serum alkaline phosphatase level was observed in four patients (two NCI grade 1, and two grade 2); and three other patients had serum lactate dehydrogenase increases to $>1.5$ times the upper limit of normal. It is not clear whether these abnormal blood test results were related to the activity of the malignant disease in these patients or to curcumin toxicity.

Although turmeric is often used to treat inflammatory skin conditions in traditional Asian medical systems, it should be noted by potential laboratory and clinical investigators that a few reports of allergic dermatitis after contact with curcumin have been published in the scientific literature [53-55]. An allergic reaction to turmeric-related products was also described in one healthy volunteer enrolled in a phase I study testing the safety of turmeric oil and turmeric extract [56]. Despite the lack of systematic testing on the interaction between curcumin with other commonly used drugs, the US Department of Health and Human Services has recommended, based on published laboratory and animal studies, that co-administration of curcumin with NSAIDs or anti-coagulant drugs (heparin, clopidogrel, aspirin) may result in an increased risk of bleeding. They have also suggested that interference may be found with other drugs that affect or are metabolized by the cytochrome P450 (CYP) enzyme system, resulting in the potential for erratic drug levels in blood [9]. In addition to this advice, it has been speculated that Curcuma extract (rather than curcumin) may potentially interfere with histamine 2-receptors antagonists (e.g., ranitidine) and proton-pump inhibitors (e.g., omeprazole) via inhibitory effects on histamine receptors [57]. Based on animal studies, other scientists have proposed that curcumin may enhance the hypoglycaemic effect of anti-diabetic medication or the efficacy of anti-lipemic drugs, via inhibition of the CYP enzyme system or reducing the low-density lipoprotein fraction in the blood $[58,59]$.

Curcumin is an approved food colouring agent in addition to a dietary item. In spite of reported minor adverse effects, large doses of up to $12.0 \mathrm{~g}$ per day of curcumin were found to be well tolerated in humans. Therefore, based on the safety and toxicity profile, in several clinical trials the targeted oral doses for curcumin can be recommended up to in between $4.0-8.0 \mathrm{~g}$ to obtain the maximum therapeutic effects.

\section{Curcumin Bioavailability}

\section{Animal model pharmacokinetics}

Recent studies on curcumin suggested as the root cause of low bioavailability in systemic circulation is due to a rapid metabolism. Curcumin administered orally at a dose of $1.0 \mathrm{~g} / \mathrm{kg}$ to rats resulted in approx. $75 \%$ of the dose being excreted in faeces and negligible amounts were detected in the urine [60]. In another study, $60 \%$ of oral curcumin was found to be absorbed and glucuronide and sulphate conjugates were detected in the urine [61]. Ravindranath et al. reported that the majority of the oral dose was found to be excreted in faeces, while approx. 35\% was excreted unchanged, and the remaining 65\% excreted as metabolites of curcumin [62]. After intravenous and intraperitoneal administration of curcumin in rats, large quantities of this compound and its metabolites were excreted in the bile, mainly as tetrahydrocurcumin and hexahydrocurcumin glucuronides [63,64]. These data offered evidence in favour of the hypotheses that curcumin undergoes transformation during absorption via the intestine and that it is possibly subject to enterohepatic recirculation [62]. These data are in accordance with the original hypothesis proposed by Holder et al. studied the fate of curcumin in rats [64].

Pan et al. have studied the intraperitoneal administration of curcumin $(0.1 \mathrm{~g} / \mathrm{kg})$ in mice, and have suggested that curcumin is first biotransformed to dihydrocurcumin and tetrahydrocurcumin, and that these compounds are subsequently converted to monoglucuronide conjugates [65]. Ireson et al. 
showed that small quantities of curcumin, hexahydrocurcumin, hexahydrocurcuminol, and hexahydrocurcumin glucuronide were present in plasma with higher levels of curcumin glucuronide and curcumin sulphate after oral dosing of curcumin in rats [66]. Interestingly, the transformation of curcumin to its metabolites occurred more extensively in rat hepatocytes grown ex vivo than in human hepatocytes. The same investigators extended their work by using suspensions of isolated human liver or gut microsomes and the results suggested that the metabolic reduction occurred very rapidly within minutes [67]. A study on a high dose of oral curcumin (2\% in the diet, or approx. $1.2 \mathrm{~g} / \mathrm{kg}$-bw) in F344 rats for 14 days showed the parent compound are detectable in plasma, liver and colon mucosal tissues ranging from 0.1 to $1.8 \mathrm{nmol} / \mathrm{g}$ tissue [46]

Due to its poor systemic bioavailability after oral administration, many research groups have focused on ways to improve its bioavailability. Co-administration of oral curcumin with piperine, an alkaloid found in black pepper (Piper nigrum) and long pepper (Piper longa), appeared to increase serum concentrations of curcumin in rodents. In a study using high doses of oral curcumin $(2.0 \mathrm{~g} / \mathrm{kg})$ in rats, co-administration of piperine increased systemic bioavailability by $154 \%$ [68]. The mechanism of this effect has not been elucidated yet.

In summary, the systemic bioavailability of curcumin after oral dosing in rodents is found low. Curcumin may undergo intestinal metabolism, and it appears it undergoes very rapid first-pass metabolism and excretion in bile. Co-administration with other agents or the use of different delivery systems may increase systemic bioavailability of curcumin.

\section{Clinical pharmacokinetics}

In contrast to the extensive preclinical evidences presented, fewer pharmacokinetic data are available from human studies. In one of the studies, $2.0 \mathrm{~g}$ of pure curcumin powder was administered orally to fasting volunteers and low curcumin concentrations in plasma $(<10 \mathrm{ng} / \mathrm{mL})$ were observed after $1 \mathrm{~h}$ [68]. In the same study, concomitant administration of $20 \mathrm{mg}$ of piperine appeared to increase bioavailability of curcumin in humans by $2000 \%$. In a study with higher doses of oral curcumin, Cheng et al. in Taiwan administered up to $8.0 \mathrm{~g}$ of curcumin daily for three months to patients with preinvasive malignant or high-risk premalignant conditions. It was found that peak serum curcumin concentrations were achieved $1-2 \mathrm{~h}$ after oral intake as $1.75 \mu \mathrm{M}$ and that levels gradually declined within $12 \mathrm{~h}$ [50]. In a dose-escalation study performed in the US, too low serum concentration of curcumin was observed (in some cases could not be detected) on administering 50-200 mg of oral micronized curcumin together with orange juice in healthy volunteers [69].

Two clinical phase I dose-escalation studies were conducted in patients with advanced colorectal cancer in Leicester, England. In the pilot study of 15 patients, standardized oral Curcuma extract (doses up to $180 \mathrm{mg}$ of curcumin) was administered in a formulation that also contained volatile oils derived from Curcuma spp., daily for up to four months. No evidence of clinical toxicity attributable to the extract was detected, however, no evidence of detectable systemic bioavailability was observed either [70]. In a subsequent phase I study in 15 patients, a curcuminoid formulation was administered orally for up to four months, allowing rapid dose escalation and equating to curcumin doses between 0.45 and $3.6 \mathrm{~g}$ daily [52]. Oral consumption of the highest dose of curcumin (3.6 g daily) resulted in detectable levels of drug and conjugates in plasma and urine, just above the limit of detection of the assay (approx. $0.63 \mathrm{ng} / \mathrm{mL}$ ). Lower doses of curcumin resulted in no detectable urinary levels of the drug. In the six patients consuming $3.6 \mathrm{~g}$ of curcumin daily, urinary levels varied between 0.1 and 1.3 $\mu \mathrm{M}$ (curcumin), 19 and $45 \mathrm{nM}$ (curcumin sulphate), and 210 and $510 \mathrm{nM}$ (curcumin glucuronide) [52].

To determine levels of curcumin in gastrointestinal tissues, further studies were performed in patients undergoing operations for colorectal cancer who offered voluntary consent to have their tissues used for research purposes [71]. Twelve patients with histologically confirmed colorectal cancer received oral curcumin $(0.45,1.8$, or $3.6 \mathrm{~g}$ daily) for seven days before surgery. Levels of agent-derived species were determined in the peripheral circulation and in colorectal tissue obtained at the time of surgical 
resection. The concentrations of curcumin in normal and malignant colorectal tissue of patients consuming $3.6 \mathrm{~g}$ daily of curcumin were 12.7 and $7.7 \mathrm{nM} / \mathrm{g}$ tissue, respectively. Curcumin sulphate and curcumin glucuronide were identified in the intestinal tissues of these patients. Trace levels of curcumin were found in the peripheral circulation. In accordance with the data from preclinical models discussed earlier, these clinical results in both volunteers and patients suggest that curcumin has low systemic bioavailability in humans and that a dose of $3.6 \mathrm{~g}$ curcumin per day achieved measurable levels of the parent compound in colorectal tissue. The same investigators examined the levels of curcumin in hepatic tissue after oral dosing in 12 patients with liver metastases from colorectal cancer who received $0.45-3.6 \mathrm{~g}$ of oral curcumin daily for seven days before hepatic surgery [72]. They measured the levels of curcumin and its metabolites in portal and peripheral blood, bile, and liver tissue. Low nanomolar levels of curcumin and its glucuronide and sulphate conjugates were found in peripheral blood samples taken $1 \mathrm{~h}$ after seventh dose of curcumin and in portal blood samples taken 6-7 h after seventh dose of curcumin. In resected liver tissue, no parent drug was detected, but trace levels of metabolic products were found. This pilot study showed that the doses of oral curcumin required to produce hepatic levels sufficient to exert pharmacologic activity are probably not feasible in humans with this pharmaceutical formulation.

In summary, the results from several pilot and phase I clinical studies in volunteers and patients are consistent with the findings obtained with curcumin in preclinical models presented earlier. Collectively, they confirm that low systemic bioavailability is achieved after oral dosing, probably due to rapid first-pass metabolism and some degree of intestinal pre-metabolism. A daily oral dose of $3.6 \mathrm{~g}$ of curcumin has been shown to result in detectable levels of curcumin in plasma, colorectal tissue and urine.

\section{Antioxidant and Anti-inflammatory Activities}

\section{Preclinical anti-oxidant activity}

Oxidative stress and oxidative damage are involved in the pathophysiology of many chronic inflammatory and degenerative disorders, particularly such as cancer [73]. The generation of ROS, particularly $\mathrm{O}_{2}{ }^{--}$and $\mathrm{OH}^{\circ}$, play important roles in the development of cancer [13-16]. Therefore in order to prevent from the oxidative damage of DNA, lipid or protein the effects of these free radicals can be diluted by the anti-oxidant mechanism.

Curcumin at the concentration of $10 \mu \mathrm{M}$ inhibited ROS generation in rat peritoneal macrophages [74] and similar effects have been observed in red blood cells [75]. Curcumin has also been shown to scavenge $\mathrm{O}_{2}{ }^{-}$and $\mathrm{OH}^{-}$radicals [76]. In contrary, a few reports showing curcumin can have both as pro-oxidant or anti-oxidant effects depending on the doses and the chemical environment (e.g., availability of free $\mathrm{Cu}^{2+}$ ions) [77-79]. Another free radical, $\mathrm{NO}$, also plays important roles as an oxidant, inflammatory agent and immune-modulator. Preclinical studies suggested that curcumin may inhibit induction of macrophage NOS activity at concentrations of 1-20 $\mu \mathrm{M}[39,80]$. In mice, oral administration of an aqueous alkaline solution of curcumin, notably at a tiny dose of $92 \mathrm{ng} / \mathrm{g}-\mathrm{bw}$ strongly inhibited murine hepatic lipopolysaccharide-induced iNOS gene expression [21]. As inhibition of $i$ NOS activity may represent a mechanism of intervention during carcinogenesis.

Endothelial heme oxygenase-1 (HO-1) is a protein induced by cellular stress. Its main action is the degradation of heme to the anti-oxidant biliberdin and the vasoactive molecule carbon monoxide (CO) [9]. Curcumin showed a dose- and time-dependent increase in HO-1 mRNA, protein expression, and heme oxygenase enzymatic activity in bovine aortic endothelial cells and human proximal renal tubular cells at the concentration of $1-8 \mu \mathrm{M}$ through the NF- $\kappa \mathrm{B}$ pathways and transcriptional mechanisms [81]. Increased heme oxygenase activity also appears to play an important role in curcumin-mediated cytoprotection against oxidative stress and NO-induced toxicity or apoptosis [82]. 
Interestingly, although curcumin shows anti-oxidant properties by providing hydrogen radicals and scavenging free radicals, there are a growing number of evidences that it can act as pro-oxidant under certain condition by generating ROS to show anticancer activity [83-85]. The balance between antioxidant and pro-oxidant activity must be considered when planning intervention trials in healthy volunteers, particularly if pro-oxidant activity results in potentially damaging effects, as shown in biomarkers such as oxidative DNA adduct levels [86].

\section{Clinical anti-oxidant activity}

In a randomized controlled trial conducted in the US by using two diet-derived polyphenolic agents, the renoprotective and anti-oxidant properties of curcumin, in combination with the natural bioflavonoid quercetin, were tested in dialysis-dependent patients with cadaveric renal transplants [87]. It is known that the implicated mechanisms in renal graft rejection include alloimmune (T-cellmediated cytotoxicity) and non-immune factors (e.g., cytomegalovirus infection, endothelial injury, and progressive atherosclerosis as a result of oxidative stress) $[88,89]$. In this study, both early graft and delayed graft functions were significantly improved in the drug (480 mg of curcumin and $20 \mathrm{mg}$ of quercetin) treated group comparing to placebo group [87]. Another interesting observation was that tremor and neurotoxicity appeared to be less common in the drug treated group than in the control group. The investigators suggested that HO-1 induction may play a role in the improved early outcomes of cadaveric renal recipients treated with curcumin and bioflavonoids [87,90].

The anti-oxidant properties of curcumin were demonstrated in another pilot study in patients with chronic, non-alcoholic, tropical pancreatitis. In this study, 20 patients were randomized to receive either $500 \mathrm{mg}$ of oral curcumin in combination with $5 \mathrm{mg}$ piperine or placebo for up to six weeks [91]. The researchers evaluated the erythrocyte levels of malondialdehyde (MDA) and glutathione (GSH) as well as effects on clinical pain patterns for assessment of abdominal pain. The MDA and GSH levels in the body are general indicators of lipid peroxidation and anti-oxidant potential, respectively. The results of this study showed that patients treated with curcumin and piperine had significantly lower levels of MDA compared with the placebo group. Conversely, erythrocyte GSH levels remained unaltered, analogous to studies that showed that high-dose curcumin did not result in glutathione-Stransferase (GST) levels reduction. In this study, pain severity was unaffected by curcumin consumption. No side effects were reported, nor laboratory toxicities documented on blood tests done before and after the treatment course [91].

Anti-oxidant effects of curcumin in preclinical studies are well documented; however a limited report appeared to explain that biomarker directly related to the anti-oxidative effects.

\section{Preclinical anti-inflammatory effects}

The arachidonic acid metabolism consists of two well-described pathways, the cyclooxygenase $(\mathrm{COX})$ and the lipooxygenase (LOX) pathways. Cyclooxygenase is the key enzyme involved in the COX pathway, converting arachidonic acid to prostaglandins and thromboxanes (Figure 5). There are two COX isozymes, namely COX-1 and COX-2. The COX-1 is a constitutive isoform expressed in most tissues; its inhibition results in adverse effects such as gastrointestinal ulcers or impairment of renal blood flow. Conversely, COX-2 is inducible at sites of inflammation by cytokines and intracellular signals; it can also be induced in various normal tissues by the hormones of ovulation and pregnancy, growth factors, oncogenes, and tumour promoters [92]. COX-2 is constitutively expressed only in brain and spinal cord tissue. COX-2 over expression has been implicated in the carcinogenesis of many tumours such as in colon, rectum, breast, head and neck, lung, pancreas, stomach, and prostate [93].

It has been shown that curcumin is able to inhibit induction of COX-2 gene expression in oral and colon epithelial cells $[94,95]$. At a concentration of $20 \mu \mathrm{M}$, curcumin showed a strong inhibition of chemically induced $\mathrm{PGE}_{2}$ production in colon cells [66]. In a study in human colon carcinoma cell lines carried by Lev-Ari et al., incubation of HT29 cells and SW480 cells with different concentrations of curcumin, resulted in inhibition of $\mathrm{PGE}_{2}$ synthesis, down regulation of $\mathrm{COX}-2$ 
protein levels, and increased apoptosis of those cells that constitutively express COX-2 protein [95]. One of the implicated mechanisms for COX-2 down regulation is inhibition of the activity of the I $\kappa \mathrm{K}$ signalling complex responsible for phosphorylation of $\mathrm{I} \kappa \mathrm{B}$ and subsequently the activation of the transcription factor NF- $\kappa \mathrm{B}$ [96]. This finding was also supported by the fact that commonly used antiinflammatory drugs such as aspirin and salicylates, which inhibit the activity of $\mathrm{I} \kappa \mathrm{B}$ kinase- $\beta$, have also been linked to a decreased incidence of colorectal cancer [97].

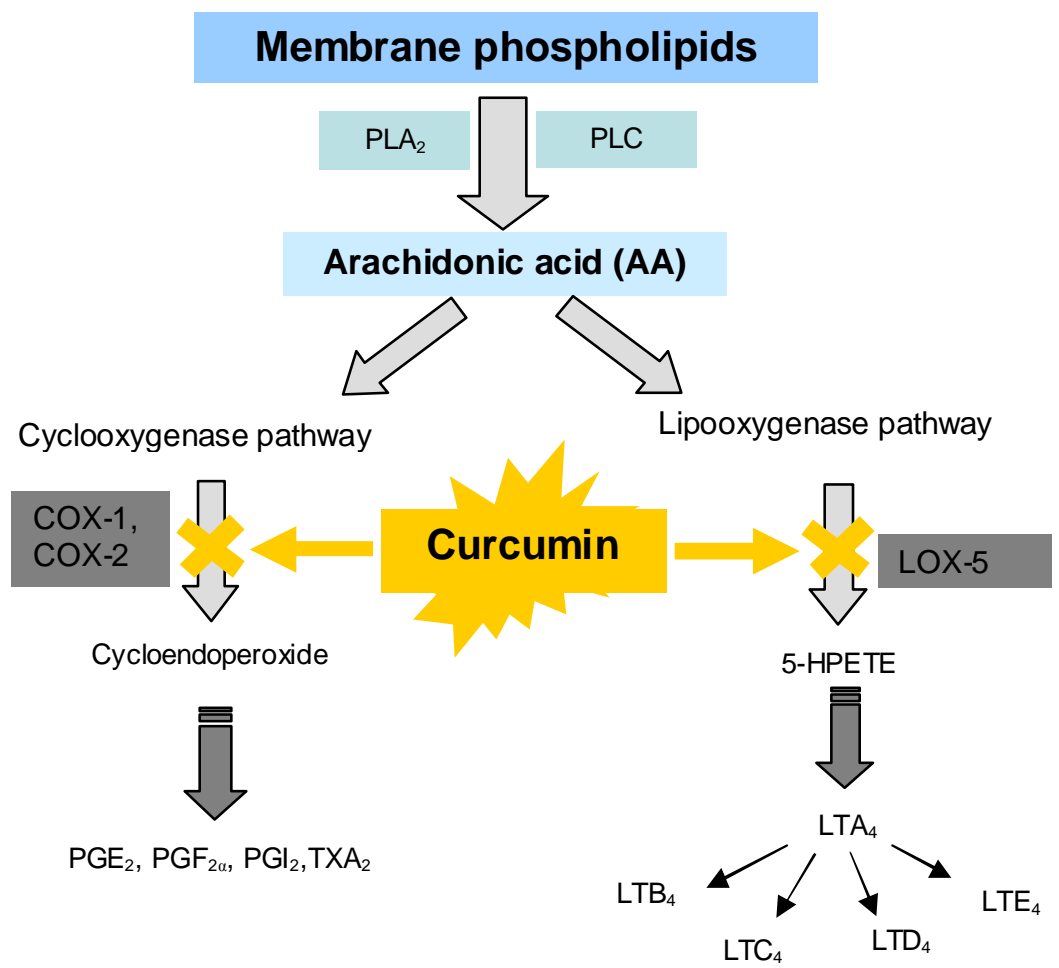

Figure 5. Flow diagram showing inhibitory effect of curcumin on arachidonic pathways.

Cyclooxygenase (COX); Lipooxygenase (LOX); Leukotriene (LT); Phospholipase (PL); Prostaglandin (PG); Thromboxane (TX); Hydroperoxyeicosatetraenoate (HPETE);

Apart from the well known roles of COX-2 [92], later studies suggest that the COX-1 isozyme also plays role in inflammation and carcinogenesis; indeed the balance between the metabolic products of COX-1 and COX-2 catalysis appears important in physiologic function and response to inflammation. Curcumin and some of its analogues do appear to inhibit COX-1 transcription [98]. Such inhibition is important, as it has been linked to a potential influence on the local spread of malignancy and the communication between malignant cells and their neighbouring stromal cells $[99,100]$.

Numerous studies have indicated that the transcription factor, NF- $\kappa \mathrm{B}$ plays important role to induce inflammation and is constitutively active in patients with cancer [101,102]. The role of NF- $\kappa \mathrm{B}$ in suppression of apoptosis, tumour growth, invasion, angiogenesis, and metastasis, via a variety of downstream effectors, is well documented. Activation of NF- $\kappa \mathrm{B}$ results in up regulation of the molecules cyclin D1, Bcl-2 [103] and Bcl-XL proteins, MMPs, growth factors receptors (GFRs), including vascular endothelial growth factors (VEGF) and epidermal growth factors (EGF), survinin, $i$ NOS [104] IL-6, IL-10, IL-18, AP-1, HO-1, and many others [102,105]. Therefore, an agent that can target NF- $\kappa \mathrm{B}$ is of interest for the treatment of pancreatic cancer. From a philosophical standpoint, as cancer and most chronic diseases have a multifactor aetiology, natural diet-derived agents such as curcumin that act at multiple cellular levels may stand a better chance of improving the prevention or management of these diseases than agents that affect a single cellular target. A pleiotropic activity in the cell is provided by ability of curcumin to inhibit multiple levels of the NF- $\kappa \mathrm{B}, \mathrm{AP}-1$, and JNK signalling pathways [106-108]. 


\section{Clinical anti-inflammatory activity}

Suppression of the inflammatory response by curcumin as discussed in the preclinical studies involves inhibition of the induction of COX-1, COX-2, $i$ NOS, and production of cytokines such as interferon- $\gamma$ $[98,109]$. It seems that many effects are achieved via suppression of the Janus kinase (JAK)-STAT signalling cascade via its effect on the Src homology 2 domain-containing protein tyrosine phosphatases (SHP)-2 [110]. In human multiple myeloma cells, curcumin has been shown to inhibit STAT3 phosphorylation and therefore to down regulate IL-6 production [109].

The effect of oral curcumin on inflammatory diseases has been investigated in a number of clinical studies in various patient groups. In a pilot open-label study conducted in New York, oral curcumin was given to five patients with ulcerative proctitis and five patients with Crohn disease (CD) [111]. All the patients with proctitis noticed an improvement, and $80 \%$ of patients with CD showed better inflammatory profiles [111]. Subsequently, a randomized double-blind, placebo-controlled study was performed in patients with ulcerative colitis (UC) [112]. Of 89 patients enrolled, half received $1.0 \mathrm{~g}$ of oral curcumin twice a day in combination with sulfasalazine or mesalazine, two aminosalicylates that are standard treatments for UC, and the other half of the patients received an aminosalicylate plus placebo. The 6-month treatment schedule showed that patients in the curcumin group had a significantly reduced rate of relapse ( $4.65 \%$ vs. $20.51 \%$ in the placebo group) [112].

In a study in postoperative patients, a significant anti-inflammatory effect was demonstrated in those receiving $400 \mathrm{mg}$ of oral curcumin thrice daily for five days compared with placebo [113]. Using similar methods, considerable improvements in the patients' symptoms were demonstrated in a double-blind study in India on patients with rheumatoid arthritis. In this study, $1.2 \mathrm{~g}$ of curcumin was administered four times daily to 18 patients with rheumatoid arthritis for two weeks, resulting in symptomatic improvement without apparent toxicity [49]. The anti-inflammatory properties of curcumin were demonstrated in two further studies examining the effects of oral curcumin on ophthalmologic diseases. In one of those, $375 \mathrm{mg}$ of curcumin was given orally thrice daily to patients with chronic anterior uveitis for three months, resulting in a suggestion of improvement in the condition with comparable efficacy to that of steroids, which are generally regarded as standard treatment [114]. In a subsequent study by the same team, the same dose of curcumin $(375 \mathrm{mg})$ was administered to eight patients with idiopathic inflammatory orbital pseudotumors for 6-22 months [115]. Half of the patients showed complete responses up to two years of follow-up. It is known that in patients with active psoriasis, increased activity of the enzyme phosphorylase kinase $(\mathrm{PhK})$ mediates and triggers molecular mechanisms for continuous cell migration and proliferation. In an early preclinical study, Reddy and Aggarwal demonstrated that curcumin is a selective inhibitor of PhK [116]. More recently, $\mathrm{PhK}$ activity was assessed in 40 patients who were divided into four groups: a group of active untreated psoriasis, one of resolving psoriasis treated with calcipotriol [vitamin D3 analogue], a group of patients receiving curcumin, and a control group with healthy subjects [117]. This study showed that $\mathrm{PhK}$ activity was much higher in untreated patients, lower in the groups treated with calcipotriol and curcumin, and even lower in the control group. The decrease in activity of $\mathrm{PhK}$ caused by curcumin and calcipotriol was associated with a suppression of keratinocyte transferrin receptor, the severity of parakeratosis, and the density of the epidermal cytotoxic $\mathrm{CD}^{+} \mathrm{T}$ cells, all considered clinical hallmarks of psoriatic activity [117].

In forty five patients with peptic ulcer-like symptoms treated with $0.6 \mathrm{~g}$ of oral curcumin, five times per day, ulcer-like symptom disappeared in 12 patients after four weeks of treatment. This response increased to $72 \%$ of patients after eight weeks of treatment, and up to $76 \%$ of patients at 12 weeks of treatment. The remaining 20 patients exhibited gastritis, erosions, or dyspepsia rather than definite ulcers as on the beginning of the treatment also reported symptomatic improvement within two weeks of the 4-week course of curcumin treatment. No treatment-related toxicities were noticed [118].

In contrast to the systemic anti-oxidant properties of oral curcumin, it has been suggested that topical application of curcumin may result in increased formation of ROS in the skin when used in combination with other therapies [119]. Such potentially pro-oxidant effects may relate to dose or 
conditions, as discussed earlier. In a study performed in Bradford, England, 15 Asian patients with acute vitiligo consumed turmeric daily and were treated with topical application of low-dose UVBactivated pseudocatalase (PC-KUS) for six months [119]. None of these patients showed any significant improvement of vitiligo. Eight patients were advised to stop turmeric consumption and continue with topical PC-KUS only twice daily. This led to a clinical improvement within two months and to an almost complete repigmentation at six months in six of the eight patients, leading the authors to suggest that turmeric was having an antagonistic effect on the treatment of the disease by PC-KUS.

\section{Clinical Anti-cancer Effects}

As it is evident that curcumin expresses anti-oxidant, anti-inflammatory, anti-angiogenic, anti-mitotic and anti-metastatic activities in vitro and in animal experiments, curcumin thus might be a promising molecule for the prevention and treatment of cancer in humans. Kuttan et al. observed the reduced size of the lesions in 10 of the 62 patients receiving topical turmeric/curcumin in oral cancers and leukoplakia however the report is lacking the control group and standard method of curcumin preparation [120].

A phase I clinical study performed in Taiwan reported the potential anti-carcinogenesis activity of curcumin in patients with preinvasive malignant or high-risk premalignant conditions [50]. Twenty five patients with recently resected cancer of the bladder, Bowen disease of the skin, uterine cervical intraepithelial neoplasia, intestinal metaplasia of the stomach, or oral leukoplakia, were administered curcumin in doses of 1.0 to $8.0 \mathrm{~g}$ ( $0.5 \mathrm{~g}$ of synthetic curcumin per capsule, $99 \%$ purity) daily for three months. No toxicities were reported for doses up to $8.0 \mathrm{~g}$ per day. Histologic improvement of the premalignant lesions was noted in one of two patients with presumed bladder carcinoma in situ, two of seven patients with oral leukoplakia, one of six patients with stomach intestinal metaplasia, one of four patients with cervical intraepithelial neoplasia (CIN), and two of six patients with Bowen disease of the skin. On the contrary, one of four patients with CIN, and one of seven patients with oral leukoplakia developed malignancy despite the treatment. Limitations for drawing definite conclusions from this study are the small numbers of patients with each high-risk conditions studied and the possible bias from the interpreting pathologists, as the study was not blinded. Further evidence to support the hypothesis that curcumin has activity against preneoplastic lesions is provided by a recent study performed at The Cleveland Clinic in Florida in patients with familial adenomatous polyposis (FAP) [121]. FAP is an autosomal dominant condition characterized by the development of numerous bowel adenomas that can transform to adenocarcinoma. Curcumin $(480 \mathrm{mg})$, in combination with quercetin $(20 \mathrm{mg})$, was administered three times per day to five patients with FAP. Four patients had the rectum preserved, and one had an ileoanal pouch. All patients showed a decrease in the number and the size of polyps compared with baseline figures [121]. These preliminary data strongly support the case for designing a randomized controlled trial of curcumin versus standard therapy for patients with FAP.

In a Phase II clinical study report of Dhillon et al., twenty-five patients each treated with $8.0 \mathrm{~g}$ per day curcumin orally for two months observed peaked plasma curcumin level from 22 to $41 \mathrm{ng} / \mathrm{mL}$ [122]. On continuing up to 18 months, two patients showed clinical biological activity. One had ongoing stable disease for more than 18 months; interestingly, one additional patient had a brief, but marked, tumour regression (73\%) accompanied by significant increases (4- to 35-folds) in serum cytokine levels (IL-6, IL-8, IL-10, and IL-1 receptor antagonists). Curcumin down-regulated the expression of NF- $\kappa \mathrm{B}$, COX-2, phosphorylated signal transducer and activator of transcription 3 in peripheral blood mononuclear cells from patients. In conclusion, although this molecule is poorly absorbed, with low nanogram levels of circulating curcumin detected at steady-state, biological activity is evident. Collectively, these clinical trials highlight the level of current translational interest in studying the biologic potential of curcumin in the treatment of premalignant conditions and established malignancies. 
In the review of Schehzad et al., a list of ongoing Phase III clinical trials with curcumin against cervical, oral, pancreatic and colon cancers in India and Israel is reported, however, the results of these clinical trials have not been published at the time of this manuscript preparation [123].

The current review is focused mainly on the effects of curcumin in inflammation and its link to cancer in general therefore it provides limited information on the details of the molecular mechanism(s) of action. Recently, Goel et al. have discussed in details the effects of curcumin on various cancers in human [124] and Wilken et al. reviewed the mechanism of anti-cancer properties of curcumin focused on head and neck squamous cell carcinoma [125]. Both reviews provide additional information on molecular mechanism of anticancer effects on curcumin.

\section{Advancements in Formulations and Delivery Systems}

Like many other natural polyphenols, curcumin is poorly soluble in water. It is well established fact that the main limitation of broader use of curcumin-based formulations is poor solubility in aqueous medium and fast metabolism [126]. Therefore, in order to increase its solubility, stability and pharmacological activities, development of improved formulations and delivery systems is expected to enhance its therapeutic effects. In this section selected curcumin formulations and delivery systems with promising applications are discussed.

The first step in development of improved curcumin formulations involves enhancement of its water solubility. It could be achieved by modification in its chemical structure. However, the modification should not affect its biological activities. Another approach would involve solubilization of curcumin in appropriate carrier such as liposomes, micelles, lipid complexes etc. Kurien et al. proposed the use of heat without heat-mediated disintegration of curcumin as a mean to increase solubility of curcumin and turmeric, resulting in 12-folds and 3-folds increase, respectively. Heat-solubilized curcumin has the potential for future in vivo and in vitro studies [127]. Zebib et al. suggested complexation of curcumin with metal ions $\left(\mathrm{Zn}^{2+}, \mathrm{Cu}^{2+}, \mathrm{Mg}^{2+}\right.$ and $\left.\mathrm{Se}^{2+}\right)$ as mean to prepare readily soluble formulation in water-glycerol $(1: 1 ; w / w)$, which remained stable towards light and heat [128]. Similarly, the complexes of curcumin with serum albumin were found to significantly increase the solubility of curcumin and, at the same time, reduce the toxic effect of amphoterecin B by delaying the erythrocyte membrane damage [129]. Chemically modified 4-arylidene curcumin derivatives were found to be more soluble and more potent anti-cancer targeted analogues than pure curcumin [130]. In addition, several attempts have also been made to prepare chemically modified curcumin in order to increase its activity against cancer and NF- $\kappa \mathrm{B}$ [131-136]. The water-soluble curcumin conjugates with two different sizes poly(ethyleneglycol) molecules exhibited enhanced cytotoxicity as compared to curcumin alone and showed potentials in anti-cancer treatment [137].

Regarding delivery systems proposed/developed for improved curcumin delivery, the selection presented below is made based on their applicability in treatment of anti-inflammatory disorders and/or cancer treatment.

The delivery systems can be primarily classified in accordance to the main material used to build the system:

i) Polymer-based implantable delivery systems: Curcumin in poly-(e-caprolactone)-based implants was developed for subcutaneous grafting achieving the maximum concentration in rat liver on day 4 post-implantation with the concentration plateau seven days. The study confirmed the potential of polymeric implants to avoid oral route and provide sustained release of incorporated curcumin [126].

ii) Micelles: Poly(ethyleneoxide)- $b$-poly( $\varepsilon$-caprolactone) micelle-encapsulated curcumin retained its cytotoxicity in both mouse melanoma and human mantle cell lymphoma cell lines [138]. Curcuminloaded poly(D,L-lactide-co-glycolide)-b-poly(ethylene glycol)-b-poly(DL-lactide-co-glycolide; PLGA-PEG-PLGA) micelles, decreased curcumin uptake by liver and spleen, and at the same time, enhanced distribution of curcumin in lung and brain, as desired [139]. 
iii) Nano-delivery systems: Nanotechnology and nanomedicine, emerging multidisciplinary areas offer huge potentials for development of delivery systems for curcumin. Nanoparticles-incorportaed curcumin achieved a 9-fold increase in oral bioavailability as compared to curcumin administered with piperine as absorption enhancer [140]. Polylactic-co-glycolic acid (PLGA) nano-formulation of curcumin resulted in a 22-fold higher oral bioavailability in rats as compared to conventional curcumin [141]. Curcumin loaded dextran sulphate-chitosan nanoparticles exhibited potential in targeting and represent one of the more promising line of curcumin research [142].

"Nanocurcumin", polymeric nanoparticle-encapsulated curcumin, inhibited the activation of the seminal transcription factor NF- $\kappa \mathrm{B}$ and reduced steady state levels of pro-inflammatory cytokines like ILs and TNF- $\alpha$ [143]. Nanocurcumin, in size range of 2-40 nm was able to ensure stronger antimicrobial potential [144]. A similar approach in reducing the size of curcumin crystals was used to produce nanosupsensions which can safely be administered in intravenous delivery [145].

Very interesting approach uses water-dispersible hybrid nanogels for intracellular delivery of curcumin in photodermal therapy [146]. Anti-inflammatory activity of curcumin could also be enhanced through delivery via o/w nanoemulsions [147].

iv) Phospholipid-based delivery systems: Most of the phospholipid-based delivery systems are nanodelivery systems as well however, they are distinguished because of the specific properties. The simplest delivery system involving phospholipid and curcumin would be curcumin-phospholipid complexes. Complexation of curcumin with phosphatidylcholine resulted in its enhanced bioavailability, improved pharmacokinetics and increased hepatoprotective activity [148]. Curcumin formulated with Meriva $^{\circledR}$ (phosphatidylcholine) showed increased bioavailability in rats [149]. Curcumin-phospholipid complex administered by oral route increased the serum concentrations of curcumin as compared to uncomplexed curcumin and maintained the effective concentrations over longer period of time [150].

Curcumin in phospholipid vesicles and lipid-nanospheres provided improved intravenous delivery of curcumin to tissue macrophages, especially bone marrow and spleen macrophages [151]. Solid lipid nanoparticles (SLN) seem to be one of the promising oral delivery systems for curcumin. Pharmacokinetic profile of curcumin in SLN showed significant improvement when evaluated in rat model [152]. More advanced formulations include transferrin-mediated SLN of curcumin for treatment of breast cancer [153]. Solid lipid nanoparticles bearing curcumin can be administered by other routes as well, such as topical for example [154]. Solid lipid nanoparticles showed enhanced antiangiogenic and anti-inflammatory activities in rat model of inflammatory bowel disease [155].

Liposomes are well established delivery system able to incorporate a wide variety of poorly soluble drugs and enable their aqueous medium-based administration [156]. Curcumin is expected to accommodate itself inside the liposomal bilayers [157]. Incorporation of curcumin showed in higher stability than that of free curcumin in phosphate buffer saline, human blood, plasma and RPMI-1640 medium with $10 \%$ calf serum [158]. Liposomal curcumin was reported to be able to consistently suppress NF- $\kappa \mathrm{B}$ binding and decrease the expression of NF- $\kappa \mathrm{B}$-regulated gene products, including COX-2 and IL-8, both of which have been implicated in tumour growth/invasiveness. It was proposed that liposomal curcumin for systemic delivery has potential in treatment of pancreatic carcinoma [159]. Liposomal curcumin showed dose-dependent growth inhibition and apoptosis in the two human colorectal cancer cell lines (LoVo and Colo205 cells) and synergetic effect with oxaliplatin, a standard chemotherapy for the malignancy [160]. Liposomal delivery system for curcumin in which liposomes were coated with prostate membrane specific antigen specific antibodies to achieve targeting showed superiority in two human prostate cancer cell lines [161]. Nude mice xenograft tumours were suppressed after 3.5 weeks of treatment with liposomal curcumin administered intravenously [162]. Takahashi et al. developed liposomal delivery system for oral administration of curcumin, for enhanced gastrointestinal absorption [163]. A liposome-based intravenous formulation of bis-demethoxy curcumin analogue showed better hepatoprotective activity comparing to its free form [164]. In line of a research relying on natural origin active ingredients, combination of liposomal forms of curcumin and resveratrol was able to significantly decrease prostatic adenocarcinoma in vivo. 
These findings suggested that liposomal phytochemicals-in-combination may reduce prostate cancer incidence [165]. Curcumin-decorated nanoliposomes with very high affinity for amyloid- $\beta-42$ peptide as vectors for targeted delivery of Alzheimer disease treatment opened the possibility to further explore the potential of vesicle-surface available curcumin in various cancer treatments, including targeted therapies [166].

The novel delivery systems provide enhanced stability, bioavailability and cellular uptake of curcumin. Whether some of the systems proposed by various research groups will indeed reach the patient therapy, remains to be seen. Moreover, dozens of patents on lipid-based formulations of curcumin were granted patents to various pharmaceutical industries in recent years, but those formulations are not discussed in this review.

\section{Conclusions}

Although the distribution of cancer in human population has been recorded all over the world, the pattern and prevalence are found to be different [167]. The results of epidemiological studies led to focus mainly on the diet and lifestyles as the principle cause for the origin of cancers. Based on the facts, for the prevention of cancer, the US department of Agriculture and the National Cancer Institute has recommended five servings of fruits and vegetables daily. Further analyses have suggested that this consumption should be even higher $[168,169]$. These recommendations are pointed to vitamin $\mathrm{C}$ and/or polyphenols. Polyphenols in the human diet are derived mainly from vegetables, fruits and spices. Drinks and beverages such as coffee, green and black tea, as well as chocolate, red wine, olive oil, nuts, etc. are also good sources of polyphenols. Many of these polyphenol-rich natural resources have been traditionally used as medicines for the prevention of diseases, as well as maintenance of youth and longevity. The recent line of studies has confirmed that these traditionally used natural remedies are strong anti-oxidant and anti-inflammatory agents. In addition, many of them play important roles in regulating the immune system and are now being investigated as chemopreventive, neuroprotective, cardioprotective and hepatoprotective agents, either acting alone or in combinations [170].

In particular, turmeric, a typical example of polyphenol-rich natural remedies, has been used for centuries in Indian traditional medicine (Ayurveda) and Traditional Chinese Medicine (TCM) [30]. Moreover turmeric, a popular curry spice, is also used as a food additive and preservative agent worldwide. Based on repeated studies, turmeric products have been characterized as safe by FDA in the USA, the Natural Health Products Directorate of Canada, and the Joint Expert Committee of FAO/WHO [45]. Curcumin, a principal polyphenol component of turmeric, is also available as an over-the-counter (OTC) supplement worldwide. Turmeric was introduced to Europe in the 13th century by Marco Polo and perhaps surprisingly, apart from an early study published in The Lancet in 1937, curcumin/turmeric has only entered extensive preclinical studies and scientific phase I and II/III clinical trial levels in the last $10-15$ years $[30,171]$.

The long history of curcumin mass use, and recent clinical trials have shown its excellent safety index. Over the last few years, a number of studies have provided evidence for several pharmacological properties of curcumin including chemosensitizing, radiosensitizing, wound-healing, antimicrobial, antiviral, antifungal, and anti-inflammatory activities [29,172]. Curcumin has been shown to inhibit several cell signalling pathways at multiple levels, affecting the expression and activity of cellular enzymes such as COX and GSTs, and influencing immunomodulation, angiogenesis, and cell-cell adhesion. Its ability to affect gene transcription and to induce apoptosis is of particular relevance to cancer chemoprevention and chemotherapy [106].

Recently, research on multicomponent drugs, especially phytochemical extracts or combination of targeted ingredients have provided more insight on additive and synergetic effects achieving optimum therapeutic effects. Use of a standardized extract such as Polyphenone E, a topical antiviral cream based on purified green tea extract has been approved as a prescription drug by FDA in 2006, would be the new trend in pharmaceutical sciences [173]. Similarly, potentially beneficial interactions 
between diet-derived polyphenols and other drugs and between individual components of the human diet have been identified. Examples of this concept include the combination of curcumin with the green tea extract, epigallocatechin-3-gallate (EGCG) [174]; curcumin combined with the flavonoid quercetin, found in apples, onions, and citrus fruits [121]. Interactions relevant to combinatorial treatment with curcumin might be important due to alteration in absorption, cellular and biological responses. For example, the combination of curcumin and genistein (a natural product derived from soya beans) appears to strongly inhibit growth of human breast MCF-7 cells synergistically [175]. It is also evident that the toxic effect of drugs like 5-flurouracil vinorelbine can be reduced by combined treatment with curcumin $[176,177]$.

The experience in cancer research revealed that targeted treatment of cancer could not often be achieved due to the adaptation and modification by the cancer cells during treatment. In this connection, curcumin, a pleiotropic molecule, seems quite promising. In addition, its additive and synergistic properties with other phytochemicals or routinely used toxic drugs explored in recent preclinical test are creating a new philosophy of safe and effective treatments. Therefore, the choice of curcumin as chemopreventive and potentially anti-cancer molecule seems promising. However, its formulation and delivery systems are urgently needed to be further standardized in systematic preclinical and clinical studies in order to make curcumin as an anti-cancer drug.

\section{Acknowledgments}

We would like to acknowledge to Phospholipid Research Centre, Heidelberg, Germany for the partial financial support on this project. 


\section{References}

1. Ravindran, J., Prasad, S., Aggarwal, B.B. Curcumin and cancer cells: How many ways can curry kill tumor cells selectively. APPS J. 11: 495-510 (2009).

2. Subramaniam, D., Ramalingam, S., Houchen, C. W., Anant, S. Cancer stem cells: a novel paradigm for cancer prevention and treatment. Mini-Rev Med. Chem., 10 359-371 (2010).

3. Hanahan, D., Weinberg, R.A. Hallmark of cancer: The next generation. Cell, 144: 646-674 (2011).

4. Azam, F., Mehta, S., Harris, A.L. Mechanisms of resistance to anti-angiogenesis therapy. Eur. J. Cancer, 46: 1323-1332 (2010).

5. Ebos, J.M., Lee, C.R., Kerbel, R.S. Tumor and host-mediated pathways of resistance and disease progression in response to anti-angiogenic therapy. Clin. Cancer Res., 15: 5020-5025 (2009).

6. Bergers, G., Hanahan, D. Modes of resistance to anti-angiogenic therapy. Nat. Rev. Cancer, 8: 592-603 (2008).

7. US National Institute of Health; http://clinicaltrials.gov/ct/search?term = curcumin/ (accessed August 23, 2011).

8. Zhou, H.; Beevers, C.S., Huang, S. The targets of curcumin. Curr. Drug Targets, 12: 332-347 (2011).

9. Strimpakos, A.S., Sharma, R.A. Curcumin: Preventative and therapeutic properties in laboratory studies and clinical trials. Antioxid. Redox Sign. 10, 511-545 (2008).

10. Basnet, P., Skalko-Basnet, N. Curcumin: An anti-inflammatory molecule from a curry spice on the path to cancer treatment. Molecules, 16: 4567-4598 (2011).

11. Balkwill, F., Mantovani, A. Inflammation and cancer: Back to Virchow? Lancet, 357: 539-545 (2001).

12. Coussens, L.M., Werb, Z. Inflammation and cancer. Nature, 420: 860-867 (2002).

13. Khan, N., Afaq, F., Mukhtar, H. Cancer chemoprevention through dietary antioxidants: Progress and promise. Antioxid. Redox Sign., 10: 475-510 (2008).

14. Aggarwal, B.B., Shishodia, S. Molecular targets of dietary agents for prevention and therapy of cancer. Biochem. Pharmacol., 71: 1397-1421 (2006).

15. Biesalski, H.K. Polyphenols and inflammation: Basic interactions. Curr. Opin. Clin. Nutr. Metab. Care, 10: 724-728 (2007).

16. Halliwell, B., Gutteridge, J.M.C. Free Radicals in Biology and Medicine, 3rd ed.; Clarendon Press: Oxford, UK, 1998.

17. Weber, W.M., Hunsaker, L.A., Gonzales, A.M., Heynekamp, J.J., Orlando, R.A., Deck, L.M., Vander Jagt, D.L. TPA-induced up-regulation of activator protein-1 can be inhibited or enhanced by analogs of the natural product curcumin. Biochem. Pharmacol., 72: 928-940 (2006).

18. Lala, P.K., Chakraborty, C. Role of nitric oxide in carcinogenesis and tumour progression. Lancet Oncol., 2: 149-156 (2001).

19. deRojas-Walker, T., Tamir, S., Ji, H., Wishnok, J.S., Tannenbaum, S.R. Nitric oxide induces oxidative damage in addition to deamination in macrophage DNA. Chem. Res. Toxicol., 8: 473477 (1995).

20. Graziewicz, M., Wink, D.A., Laval, F. Nitric oxide inhibits DNA ligase activity: Potential mechanisms for NO-mediated DNA damage. Carcinogenesis, 17: 2501-2505 (1996).

21. Chan, M.M., Huang, H.I., Fenton, M.R., Fong, D. In vivo inhibition of nitric oxide synthase gene expression by curcumin: A cancer preventive natural product with anti-inflammatory properties. Biochem. Pharmacol., 55: 1955-1962 (1998).

22. Von Knethen, A., Brüne, B. Cyclooxygenase-2: An essential regulator of NO-mediated apoptosis. FASEB J., 11: 887-895 (1997).

23. von Knethen, A., Callsen, D., Brune, B. NF- $\kappa$ B and AP-1 activation by nitric oxide attenuated apoptotic cell death in RAW 264.7 macrophages. Mol. Biol. Cell, 10: 361-372 (1999).

24. Chung, S.W., Hall, S.R., Perella, M.A. Role of hame oxygenase-1 in microbial host defense. Cell. Microbiol., 11: 199-207 (2009).

25. Finkel, T., Holbrook, N.J. Oxidants, oxidative stress and the biology of ageing. Nature, 408: 239-247 (2000). 
26. Baron, J.A., Sandler, R.S. Non-steroidal anti-inflammatory drugs and cancer prevention. Annu. Rev. Med., 51: 511-523 (2000).

27. Garcia-Rodriguez, L.A., Huerta-Alvarez, C. Reduced risk of colorectal cancer among long-term users of aspirin and non-aspirin non-steroidal anti-inflammatory drugs. Epidemiology, 12: 88-93 (2001).

28. Williams, C.S., Mann, M., DuBois, R.N. The role of cyclooxygenases in inflammation, cancer and development. Oncogene, 18: 7908-7916 (1999).

29. Zidi, I., Mestri, S., Bartegi, A., Ben Amor, N. TNF- $\alpha$ and its inhibitors in cancer. Med. Oncol., 27: 185-198 (2010).

30. Advances in experimental medicine and biology. In The Molecular Target and Therapeutic Uses of Curcumin in Health and Disease, Aggarwal, B.B., Surh, Y.J., Shishodia, S., Eds.; Springer: New York, USA, 2007.

31. World Health Organization. Rhizoma Curcumae Longae, WHO Monographs on Selected Medicinal Plants. WHO, Geneva, Switzerland, Volume 1, pp. 115-124, 1999.

32. Ploto, A. Turmeric: Post-Production Management for Improved Market Access for Herbs and Spices-Turmeric. Food and Agriculture Organization of the United Nations (FAO): Rome, Italy, 2003.

33. Spices Board of India. Ministry of Commerce. http://www.indianspices.com/ (accessed August 23, 2011).

34. Jayaprakasha, G.K., Rao L.J.M., Sakariah, K.K. Chemistry and biological activities of C. longa. Trends Food Sci. Technol. 16, 533-548 (2005).

35. Vogel, H.A., Pelletier, J. Curcumin-biological and medicinal properties. J. Pharma. 2: 50 (1815).

36. Milobedzka, J., Kostanecki, V., Lampe, V. Structure of curcumin. Ber. Dtsch. Chem. Ges., 43, 2163-2170 (1910).

37. Roughley, P.J., Whiting, D.A. Experiments in the biosynthesis of curcumin. J. Chem. Soc. Perkin Trans. 1, 20, 2379-2388 (1973).

38. Payton, F., Sandusky, P., Alworth, W.L. NMR study of the solution structure of curcumin. $J$. Nat. Prod., 70, 143-146 (2007).

39. Basnet, P., Tho, I., Skalko-Basnet, N. Curcumin, a wonder drug of 21st century: liposomal delivery system targeting vaginal inflammation. ICCMR 2010: $5^{\text {th }}$ International Congress on Complementary Medicine Research, Abstract: p 22 (2010).

40. Jovanovic, S.V., Steenken, S., Boone, C.W., Simic, M.G. H-atom transfer is a preferred antioxidant mechanism of curcumin. J. Am. Chem. Soc. 121: 9677-9681 (1999).

41. Wang, Y.J., Pan, M.H., Cheng, A.L., Lin, L.I., Ho, Y.S., Hsieh, C.Y., Lin, J.K. Stability of curcumin in buffer solutions and characterization of its degradation products. J. Pharm. Biomed. Anal., 15: 1867-1876 (1997).

42. Tonnesen, H.H., Karlsen, J., van Henegouwen, G.B. Studies on curcumin and curcuminoids, VIII: Photochemical stability of curcumin. Z. Lebensm. Unters Forsch., 183: 116-122 (1986).

43. Eigner, D., Scholz, D. Ferula asa-foetida and Curcuma longa in traditional medical treatment and diet in Nepal. J. Ethnopharmacol., 67: 1-6 (1999).

44. Chainani-Wu, N. Safety and anti-inflammatory activity of curcumin: A component of turmeric (Curcuma longa). J. Altern. Complement. Med., 9: 161-168 (2003).

45. National Cancer Institute. Clinical development plan: Curcumin. J. Cell. Biochem. Suppl., 26, 72-85 (1996).

46. Sharma, R.A., Ireson, C.R., Verschoyle, R.D., Hill, K.A., Williams, M.L., Leuratti, C., Manson, M.M., Marnett, L.J., Steward, W.P., Gescher, A. Effects of dietary curcumin on glutathione Stransferase and malondialdehyde-DNA adducts in rat liver and colon mucosa: Relationship with drug levels. Clin. Cancer Res., 7: 1452-1458 (2001).

47. Perkins, S., Verschoyle, R.D., Hill, K., Parveen, I., Threadgill, M.D., Sharma, R.A., Williams, M.L., Steward, W.P., Gescher, A.J. Chemopreventive efficacy and pharmacokinetics of curcumin in the min/+ mouse, a model of familial adenomatous polyposis. Cancer Epidemiol. Biomarker. Prev., 11: 535-540 (2002).

48. Ganiger, S., Malleshappa, H.N., Krishnappa, H., Rajashekhar, G., Rao, R.V., Sullivan, F. A two generation reproductive toxicity study with curcumin, turmeric yellow, in Wistar rats. Food Chem. Toxicol., 45: 64-69 (2007). 
49. Deodhar, S.D., Sethi, R., Srimal, R.C. Preliminary study on anti-rheumatic activity of curcumin (diferuloyl methane). Indian J. Med. Res., 71: 632-634 (1980).

50. Cheng, A.L., Hsu, C.H., Lin, J.K., Hsu, M.M., Ho, Y.F., Shen, T.S., Ko, J.Y., Lin, J.T., Lin, B.R., Ming-Shiang, W., et al. Phase I clinical trial of curcumin, a chemopreventive agent, in patients with high-risk or pre-malignant lesions. Anticancer Res., 21: 2895-2900 (2001).

51. Lao, C.D., Ruffin, M.T., Normolle, D., Heath, D.D., Murray, S.I., Bailey, J.M., Boggs, M.E., Crowell, J., Rock, C.L., Brenner, D.E. Dose escalation of a curcuminoid formulation. BMC Complement. Altern. Med., 6: 10 (2006).

52. Sharma, R.A., Euden, S.A., Platton, S.L., Cooke, D.N., Shafayat, A., Hewitt, H.R., Marczylo, T.H., Morgan, B., Hemingway, D., Plummer, S.M., Pirmohamed, M., Gescher, A.J., Steward, W.P. Phase I clinical trial of oral curcumin: biomarkers of systemic activity and compliance. Clin. Cancer Res. 10: 6847-6854 (2004).

53. Goh, C.L., Ng, S.K. Allergic contact dermatitis to Curcuma longa (turmeric). Contact Dermatitis, 17: 186 (1987).

54. Liddle, M., Hull, C., Liu, C., Powell, D. Contact urticaria from curcumin. Dermatitis, 17: 196197 (2006).

55. Thompson, D.A., Tan, B.B. Tetrahydrocurcumin-related allergic contact dermatitis. Contact Dermatitis, 55: 254-255 (2006).

56. Joshi, J., Ghaisas, S., Vaidya, A., Vaidya, R., Kamat, D.V., Bhagwat, A.N., Bhide, S. Early human safety study of turmeric oil (Curcuma longa oil) administered orally in healthy volunteers. J. Assoc. Phys. India, 51: 1055-1060 (2003).

57. Kim, D.C., Kim, S.H., Choi, B.H., Baek, N.I., Kim, D., Kim, M.J., Kim, K.T. Curcuma longa extract protects against gastric ulcers by blocking $\mathrm{H}_{2}$ histamine receptors. Biol. Pharm. Bull., 28: 2220-2224 (2005).

58. Babu, P.S., Srinivasan, K. Hypolipidemic action of curcumin: the active principle of turmeric (Curcuma longa) in streptozotocin-induced diabetic rats. Mol. Cell. Biochem., 166: 169-175 (1997).

59. Fan, C., Wo, X., Qian, Y., Yin, J., Gao, L. Effect of curcumin on the expression of LDL receptor in mouse macrophages. J. Ethnopharmacol., 105: 251-254 (2006).

60. Wahlstrom, B., Blennow, G. A study on the fate of curcumin in the rat. Acta Pharmacol. Toxicol. (Copenh), 43, 86-92 (1978).

61. Ravindranath, V., Chandrasekhara, N. Absorption and tissue distribution of curcumin in rats. Toxicol., 16: 259-265 (1980).

62. Ravindranath, V., Chandrasekhara, N. In vitro studies on the intestinal absorption of curcumin in rats. Toxicol., 20: 251-257 (1981).

63. Ravindranath, V., Chandrasekhara, N. Metabolism of curcumin: Studies with $\left[{ }^{3} \mathrm{H}\right]$ curcumin. Toxicol., 22: 337-344 (1981).

64. Holder, G.M., Plummer, J.L., Ryan, A.J. The metabolism and excretion of curcumin (1,7-bis-(4hydroxy-3-methoxyphenyl)-1,6- heptadiene-3,5-dione) in the rat. Xenobiotica, 8: 761-768 (1978).

65. Pan, M.H., Huang, T.M., Lin, J.K. Biotransformation of curcumin through reduction and glucuronidation in mice. Drug Metab. Dispos., 27: 486-494 (1999).

66. Ireson, C.R., Orr, S., Jones, D.J., Verschoyle, R., Lim, C.K., Luo, J.L., Howells, L., Plummer, S., Jukes, R., Williams, M.L., et al. Characterization of metabolites of the chemopreventive agent curcumin in human and rat hepatocytes and in the rat in vivo, and evaluation of their ability to inhibit phorbol ester-induced prostaglandin $\mathrm{E}_{2}$ production. Cancer Res., 61: 1058-1064 (2001).

67. Ireson, C.R., Jones, D.J., Orr, S., Coughtrie, M.W., Boocock, D.J., Williams, M.L., Farmer, P.B., Steward, W.P., Gescher, A.J. Metabolism of the cancer chemopreventive agent curcumin in human and rat intestine. Cancer Epidemiol. Biomarker Prev., 11: 105-111 (2002).

68. Shoba, G., Joy, D., Joseph, T., Majeed, M., Rajendran, R., Srinivas, P.S. Influence of piperine on the pharmacokinetics of curcumin in animals and human volunteers. Planta Med., 64: 353-356 (1998).

69. Vareed, S.K., Kakarala, M., Ruffin, M.T., Crowell, J.A., Normolle, D.P., Djuric, Z., Brenner, D.E. Pharmacokinetics of curcumin conjugate metabolites in healthy human subjects. Cancer Epidemiol. Biomarker Prev., 17: 1411-1417 (2008). 
70. Sharma, R.A., McLelland, H.R., Hill, K.A., Ireson, C.R., Euden, S.A., Manson, M.M., Pirmohamed, M., Marnett, L.J., Gescher, A.J., Steward, W.P. Pharmacodynamic and pharmacokinetic study of oral Curcuma extract in patients with colorectal cancer. Clin. Cancer Res., 7: 1894-1900 (2001).

71. Garcea, G., Berry, D.P., Jones, D.J., Singh, R., Dennison, A.R., Farmer, P.B., Sharma, R.A., Steward, W.P., Gescher, A.J. Consumption of the putative chemopreventive agent curcumin by cancer patients: assessment of curcumin levels in the colorectum and their pharmacodynamic consequences. Cancer Epidemiol. Biomarker. Prev., 14: 120-125 (2005).

72. Garcea, G., Jones, D.J., Singh, R., Dennison, A.R., Farmer, P.B., Sharma, R.A., Steward, W.P., Gescher, A.J., Berry, D.P. Detection of curcumin and its metabolites in hepatic tissue and portal blood of patients following oral administration. Br. J. Cancer, 90: 1011-1015 (2004).

73. Jang, J.H., Surh Y.J. (Ed. Surh Y.J. and Packer L.) Oxidative Stress, Inflammation and Health Taylor and Francis Group, Singapore, pp 445-447, 2005.

74. Joe, B., Lokesh, B.R. Role of capsaicin, curcumin and dietary n-3 fatty acids in lowering the generation of reactive oxygen species in rat peritoneal macrophages. Biochim. Biophys. Acta, 1224: 255-263 (1994).

75. Kunchandy, E., Rao, M.N.A. Oxygen radical scavenging activity of curcumin. Int. J. Pharm., 58: 237-240 (1990).

76. Sreejayan, N., Rao, M.N. Free radical scavenging activity of curcuminoids. Arzneimittelforschung, 46: 169-171 (1996).

77. Ahsan, H., Parveen, N., Khan, N.U., Hadi, S.M. Pro-oxidant, anti-oxidant and cleavage activities on DNA of curcumin and its derivatives, demethoxycurcumin and bisdemethoxycurcumin. Chem. Biol. Interact., 121: 161-175 (1999).

78. Tonnesen, H.H., Greenhill, J.V. Studies on curcumin and curcuminoids: 22. curcumin as a reducing agent and as a radical scavenger. Int. J. Pharm., 87: 79-87 (1992).

79. Barik, A., Mishra, B., Shen, L., Mohan, H., Kadam, R.M., Dutta, S., Zhang, H.Y., Priyadarsini, K.I. Evaluation of a new copper(II)-curcumin complex as superoxide dismutase mimic and its free radical reactions. Free Radical Biol. Med., 39: 811-822 (2005).

80. Brouet, I., Ohshima, H. Curcumin, an anti-tumour promoter and anti-inflammatory agent, inhibits induction of nitric oxide synthase in activated macrophages. Biochem. Biophys. Res. Commun., 206: 533-540 (1995).

81. Hill-Kapturczak, N.: Thamilselvan, V., Liu, F., Nick, H.S., Agarwal, A. Mechanism of heme oxygenase-1 gene induction by curcumin in human renal proximal tubule cells. Am. J. Physiol. Renal Physiol., 281: F851-F859 (2001).

82. Motterlini, R., Foresti, R., Bassi, R., Green, C.J. Curcumin, an antioxidant and anti-inflammatory agent, induces heme oxygenase- 1 and protects endothelial cells against oxidative stress. Free Radical Biol. Med., 28: 1303-1312 (2000).

83. Kelkel, M., Jacob, C., Dicato, M., Diederich, M. Potential of the dietary antioxidants resveratrol and curcumin in prevention and treatment of hematologic malignancies. Molecules, 15: 70357074 (2010).

84. Chen, J., Wanming, D., Zhang, D., Liu, Q., Kang, J. Water-soluble antioxidants improve the antioxidant and anticancer activity of low concentrations of curcumin in human leukemia cells. Pharmazie, 60: 57-61 (2005).

85. Galati, G., Sabzevari, O., Wilson, J.X., O'Brien, P.J. Prooxidant activity and cellular effects of the phenoxyl radicals of dietary flavonoids and other polyphenolics. Toxicol., 177: 91-104 (2002).

86. Nair, J., Strand, S., Frank, N., Knauft, J., Wesch, H., Galle, P.R., Bartsch, H. Apoptosis and agedependant induction of nuclear and mitochondrial etheno-DNA adducts in Long-Evans Cinnamon (LEC) rats: Enhanced DNA damage by dietary curcumin upon copper accumulation. Carcinogenesis, 26: 1307-1315 (2005).

87. Shoskes, D., Lapierre, C., Cruz-Correa, M., Muruve, N., Rosario, R., Fromkin, B., Braun, M., Copley, J. Beneficial effects of the bioflavonoids curcumin and quercetin on early function in cadaveric renal transplantation: A randomized placebo controlled trial. Transplantation, 80: 1556-1559 (2005). 
88. Joosten, S.A., Sijpkens, Y.W., van Kooten, C., Paul, L.C. Chronic renal allograft rejection: Pathophysiologic considerations. Kidney Int., 68: 1-13 (2005).

89. Shaikewitz, S.T., Chan, L. Chronic renal transplant rejection. Am. J. Kidney Dis., 23: 884-893 (1994).

90. Avihingsanon, Y., Ma, N., Csizmadia, E., Wang, C., Pavlakis, M., Giraldo, M., Strom, T.B., Soares, M.P., Ferran, C. Expression of protective genes in human renal allografts: A regulatory response to injury associated with graft rejection. Transplantation, 73: 1079-1085 (2002).

91. Durgaprasad, S., Ganesh Pai, C., Vasanthkumar, Alvres, J.F., Sanjeeva, Namitha. A pilot study of the anti-oxidant effect of curcumin in tropical pancreatitis. Indian J. Med. Res., 122: 315-318 (2005)

92. Taketo, M.M. Cyclooxygenase-2 inhibitors in tumorigenesis (Part II). J. Natl. Cancer Inst., 90: 1609-1620 (1998).

93. Sharma, R.A. Translational medicine: targeting cyclo-oxygenase isozymes to prevent cancer. QJM, 95: 267-273 (2002).

94. Zhang, F., Altorki, N.K., Mestre, J.R., Subbaramaiah, K., Dannenberg, A.J. Curcumin inhibits cyclooxygenase-2 transcription in bile acid- and phorbol ester-treated human gastrointestinal epithelial cells. Carcinogenesis, 20: 445-451 (1999).

95. Lev-Ari, S., Maimon, Y., Strier, L., Kazanov, D., Arber, N. Down-regulation of prostaglandin $\mathrm{E}_{2}$ by curcumin is correlated with inhibition of cell growth and induction of apoptosis in human colon carcinoma cell lines. J. Soc. Integr. Oncol., 4: 21-26 (2006).

96. Plummer, S.M., Holloway, K.A., Manson, M.M., Munks, R.J., Kaptein, A., Farrow, S., Howells, L. Inhibition of cyclo-oxygenase 2 expression in colon cells by the chemopreventive agent curcumin involves inhibition of NF- $\kappa \mathrm{B}$ activation via the NIK/IKK signalling complex. Oncogene, 18: 6013-6020 (1999).

97. Yin, M.J., Yamamoto, Y., Gaynor, R.B. The anti-inflammatory agents aspirin and salicylate inhibit the activity of IкB kinase- $\beta$. Nature, 396: 77-80 (1998).

98. Handler, N., Jaeger, W., Puschacher, H., Leisser, K., Erker, T. Synthesis of novel curcumin analogues and their evaluation as selective cyclooxygenase-1 (COX-1) inhibitors. Chem. Pharm. Bull., 55: 64-71 (2007).

99. Su, C.C., Chen, G.W., Lin, J.G., Wu, L.T., Chung, J.G. Curcumin inhibits cell migration of human colon cancer colo 205 cells through the inhibition of nuclear factor kappa B/p65 and down-regulates cyclooxygenase- 2 and matrix metalloproteinase-2 expressions. Anticancer Res., 26: $1281-1288$ (2006).

100. Tsujii, M., Kawano, S., Tsuji, S., Sawaoka, H., Hori, M., DuBois, R.N. Cyclooxygenase regulates angiogenesis induced by colon cancer cells. Cell, 93: 705-716 (1998).

101. Wang, W., Abbruzzese, J.L., Evans, D.B., Larry, L., Cleary, K.R., Chiao, P.J. The nuclear factor$\kappa \mathrm{B}$ RelA transcription factor is constitutively activated in human pancreatic adenocarcinoma cells. Clin. Cancer Res., 5: 119-127 (1999).

102. Aggarwal, B.B. Nuclear factor- $\kappa$ B: The enemy within. Cancer Cell, 6: 203-208 (2004).

103. Aggarwal S, Takada Y, Singh S, Myers JN, and Aggarwal BB. Inhibition of growth and survival of human head and neck squamous cell carcinoma cells by curcumin via modulation of nuclear factor-kappaB signaling. Int J Cancer 111: 679-692, 2004.

104. Surh YJ, Chun KS, Cha HH, Han SS, Keum YS, Park KK, and Lee SS. Molecular mechanisms underlying chemopreventive activities of anti-inflammatory phytochemicals: down-regulation of COX-2 and iNOS through suppression of NF- $\kappa \mathrm{B}$ activation. Mutat Res/Fundamental Mol Mech Mutagen 480-481: 243-268, 2001.

105. Aggarwal S, Ichikawa H, Takada Y, Sandur SK, Shishodia S, and Aggarwal BB. Curcumin (diferuloylmethane) down-regulates expression of cell proliferation and antiapoptotic and metastatic gene products through suppression of IkappaBalpha kinase and Akt activation. $\mathrm{Mol}$ Pharmacol 69: 195-206, 2006.

106. Aggarwal, B.B., Kumar, A., Bharti, A.C. Anticancer potential of curcumin: Preclinical and clinical studies. Anticancer Res., 23: 36398 (2003).

107. Chen, Y.R., Tan, T.H. Inhibition of the c-Jun N-terminal kinase (JNK) signaling pathway by curcumin. Oncogene, 17: 173-178 (1998).

108. Huang, T.S., Lee, S.C., Lin, J.K. Suppression of c-Jun/AP-1 activation by an inhibitor of tumor promotion in mouse fibroblast cells. Proc. Natl. Acad. Sci. USA, 88: 5292-5296 (1991). 
109. Bharti, A.C., Donato, N., Singh, S., Aggarwal, B.B. Curcumin (diferuloylmethane) down-regulates the constitutive activation of nuclear factor- $\kappa \mathrm{B}$ and $\mathrm{I} \kappa \mathrm{B} \alpha$ kinase in human multiple myeloma cells, leading to suppression of proliferation and induction of apoptosis. Blood, 101: 1053-1062 (2003).

110. Kim, H.Y., Park, E.J., Joe, E.H., Jou, I. Curcumin suppresses Janus kinase-STAT inflammatory signaling through activation of Src homology 2 domain-containing tyrosine phosphatase 2 in brain microglia. J. Immunol., 171: 6072-6079 (2003).

111. Holt, P.R., Katz, S., Kirshoff, R. Curcumin therapy in inflammatory bowel disease: A pilot study. Dig. Dis. Sci., 50: 2191-2193 (2005).

112. Hanai, H., Iida, T., Takeuchi, K., Watanabe, F., Maruyama, Y., Andoh, A., Tsujikawa, T., Fujiyama, Y., Mitsuyama, K., Sata, M., et al. Curcumin maintenance therapy for ulcerative colitis: Randomized, multicenter, double-blind, placebo-controlled trial. Clin. Gastroenterol. Hepatol., 4: 1502-1506 (2006).

113. Satoskar, R.R., Shah, S.J., Shenoy, S.G. Evaluation of anti-inflammatory property of curcumin (diferuloyl methane) in patients with postoperative inflammation. Int. J. Clin. Pharmacol. Ther. Toxicol., 24: 651-654 (1986).

114. Lal, B., Kapoor, A.K., Asthana, O.P., Agrawal, P.K., Prasad, R., Kumar, P., Srimal, R.C. Efficacy of curcumin in the management of chronic anterior uveitis. Phytother. Res., 13: 318-322 (1999).

115. Lal, B., Kapoor, A.K., Agrawal, P.K., Asthana, O.P., Srimal, R.C. Role of curcumin in idiopathic inflammatory orbital pseudotumours. Phytother. Res., 14: 443-447 (2000).

116. Reddy, S., Aggarwal, B.B. Curcumin is a non-competitive and selective inhibitor of phosphorylase kinase. FEBS Lett., 341: 19-22 (1994).

117. Heng, M.C., Song, M.K., Harker, J., Heng, M.K. Drug-induced suppression of phosphorylase kinase activity correlates with resolution of psoriasis as assessed by clinical, histological and immunohistochemical parameters. Br. J. Dermatol., 143: 937-949 (2000).

118. Prucksunand, C., Indrasukhsri, B., Leethochawalit, M., Hungspreugs, K. Phase II clinical trial on effect of the long turmeric (Curcuma longa Linn) on healing of peptic ulcer. Southeast Asian J. Trop. Med. Pub. Health, 32: 208-215 (2001).

119. Schallreuter, K.U., Rokos, H. Turmeric (curcumin): A widely used curry ingredient, can contribute to oxidative stress in Asian patients with acute vitiligo. Indian J. Dermatol. Venereol. Leprol., 72: 57-59 (2006).

120. Kuttan, R., Sudheeran P.C., Josph C.D. Turmeric and curcumin as topical agents in cancer therapy. Tumori, 73: 29-31 (1987).

121. Cruz-Correa, M., Shoskes, D.A., Sanchez, P., Zhao, R., Hylind, L.M., Wexner, S.D., Giardiello, F.M. Combination treatment with curcumin and quercetin of adenomas in familial adenomatous polyposis. Clin. Gastroenterol. Hepatol., 4: 1035-1038 (2006).

122. Dhillon, N., Aggarwal, B.B., Newman, R.A., Wolf, R.A., Kunnumakkara, A.B., Abbruzzese J.L., Ng, C.S., Badmaev, V., Kurzrock, R. Phase II trial of curcumin in patients with advanced pancreatic cancer. Clin. Cancer Res., 14: $4491-4499$ (2008).

123. Shehzad, A., Wahid, F., Lee, Y.S. Curcumin in cancer chemoprevention: Molecular targets, pharmacokinetics, bioavailability, and clinical trials. Archiv Pharm. Chem. Life Sci., 343: 489499 (2010).

124. Goel, A., Aggarwal, B.B. Curcumin, the golden spice from Indian saffron, is a chemosensitizer and radiosensitizer for tumors and chemoprotector and radioprotector for normal organs. Nutr. Cancer, 62: 919-930 (2010).

125. Wilken, R., Veena, M.S., Wang, M.B., Srivatsan, E.S. Curcumin: A review of anti-cancer properties and therapeutic activity in head and neck squamous cell carcinoma. Mol. Cancer, 10: 1-19 (2011).

126. Bansal, S.S., Vadhanam, M.V., Gupta, R.C. Development and in vitro-in vivo evaluation of polymeric implants for continuous systemic delivery of curcumin. Pharm. Res., 28: 1121-1130 (2011).

127. Kurien, B.T., Scofield, R.H. Oral administration of heat-solubilized curcumin for potentially increasing curcumin bioavailability in experimental animals. Int. J. Cancer, 125: 1992-1993 (2009). 
128. Zebib, B., Mouloungui, Z., Noirot, V. Stabilization of curcumin by complexation with divalent cations in glycerol/water system. Bioinorg. Chem. Appl., Art ID 292760: 8 pages, (2010).

129. Kudva, A.K., Manoj, M.N., Swamy, B.N., Ramadoss, C.S. Complexation of amphoterecin B and curcumin with serum albumin: Solubility and effect on erythrocyte membrane damage. J. Expt. Pharmacol., 3: 1-6 (2011).

130. Qiu, X., Du, Y., Lou, B., Zuo, Y., Shao, W., Huo, Y., Huang, J., Yu, Y., Zhou, B., Du, J., Fu, H., $\mathrm{Bu} \mathrm{X}$. Synthesis and identification of new 4-arylidene curcumin analogues as potential anticancer agents targeting nuclear factor- $\kappa \mathrm{B}$ signaling pathway. J. Med. Chem., 53: 8260-8273 (2010).

131. Ohtsu, H., Xiao, Z., Ishida, J., Nagai, M., Wang, H., Itokawa, H., Su, C., Shih, C., Chiang, T., Chang, E. Antitumor agents. 217. Curcumin analogues as novel androgen receptor antagonists with potential as anti-prostate cancer agents. J. Med. Chem., 45: 5037-5042 (2002).

132.Lin, L., Shi, Q., Nyarko, A., Bastow, K., Wu, C., Su, C., Shih, C., Lee, K. Antitumor agents. 250. Design and synthesis of new curcumin analogs as potential anti-prostate cancer agents. J. Med. Chem., 49: 3963-3972 (2006).

133. Zambre, A.P., Kulkarni, V.M., Padhye, S., Sandur, S.K., Aggarwal, B.B. Novel curcumin analogs and proliferation targeting TNF-induced NF- $\kappa$ B activation in human leukemic KBM-5 cells. Bioorg. Med. Chem., 14: 7196-7204 (2006).

134. Weber, W.M., Hunsaker, L.A., Roybal, C.N., Bobrovnikova-Marjon, E.V., Abcouwer, S.F., Royer, R.E., Deck, L.M., Vander Jagt, D.L. Activation of NF- $\kappa$ B is inhibited by curcumin and related enones. Bioorg. Med. Chem., 14: 2450-2461 (2006).

135. Adams, B., Ferstl, E., Davis, M., Herold, M., Kurtkaya, S., Camalier, R., Hollingshead, M., Kaur, G., Sausville, E., Rickles, F. Synthesis and biological evaluation of novel curcumin analogs as anti-cancer and anti-angiogenesis agents. Bioorg. Med. Chem., 12: 3871-3883 (2004).

136. Padhye, S., Chavan, D., Pandey, S., Deshpande, J., Swamy, K.V., Sarkar, F.H. Perspectives on chemopreventive and therapeutic potential of curcumin analogs in medicinal chemistry. Med. Chem., 10: 372-387 (2010).

137. Safavy, A., Raisch, K.P., Mantena, S., Sanford, L.L., Sham, S.W., Rama Krishna, N., Bonner, J.A. Design and development of water-soluble curcumin conjugates as potential anti-cancer agents. J. Med. Chem., 50: 6284-6288 (2007).

138. Ma, Z., Haddadi, A., Molavi, O., Lavasanifar, A., Lai, R., Samuel, J. Micelles of poly(ethylene oxide)-b-poly( $\varepsilon$-caprolactone) as vehicles for the solubilization, stabilization, and controlled delivery of curcumin. J. Biomed. Materials Res. Part A, 86A: 300-310 (2008).

139. Song, Z., Feng, R., Sun, M., Guo, C., Gao, Y., Li, L., Zhai, G. Curcumin-loaded PLGA-PEGPLGA triblock copolymeric micelles: Preparation, pharmacokinetics and distribution in vivo. $J$. Colloid Interface Sci., 354: 116-123 (2011).

140. Shaikh, J., Ankola, D.D., Beniwal, V., Singh, D., Ravi Kumar, M.N.V. Nanoparticle encapsulation improves oral bioavailability of curcumin by at least 9-fold when compared to curcumin administered with piperine as absorption enhancer. Eur. J. Pharm. Sci., 37: 223-230 (2009).

141. Tsai, Y.M., Jan, W.C., Chien, C.F., Lee, W.C., Lin, L.C., Tsai, T.H. Optimized nano-formulation on the bioavailability of hydrophobic polyphenol, curcumin, in freely-moving rats. Food Chem., 127: 918-925 (2011).

142. Anitha, A., Deepagan, V.G., Divya Rani, V.V., Menon, D., Nair, S.V., Jayakumar, R. Preparation, characterization, in vitro drug release and biological studies of curcumin loaded dextran sulphate-chitosan nanoparticles. Carbohyd. Polym., 84: 1158-1164 (2011).

143. Bisht, S., Feldmann, G., Soni, S., Ravi, R., Karikar, C., Maitra, A.. Polymeric nanoparticleencapsulated curcumin ("nanocurcumin"): A novel strategy for human cancer therapy. $J$. Nanobiotechnol., 5: 1-18 (2007).

144. Bhawana, Basniwal, R.K., Buttar, H.S., Jain, V.K., Jain, N. Curcumin nanoparticles: preparation, characterization, and antimicrobial study. J. Agric. Food Chem., 59: 2056-2061 (2011).

145. Gao, Y., Li, Z., Sun, M., Guo, C., Yu, A., Xi, Y., Cui, J., Lou, H., Zhai, G. Preparation and characterization of intravenously injectable curcumin nanosuspension. Drug Deliv., 18: 131-142 (2011). 
146. Wu W., Shen J., Banerjee P., Zhou S. Water-dispersible multifunctional hybrid nanogels for combined curcumin and photothermal therapy. Biomaterials, 32: 598-609 (2011).

147. Wang, X., Jiang, Y., Wang, Y.W., Huang, M.T., Ho, C.T., Huang, Q. Enhancing anti-inflammation activity of curcumin through O/W nanoemulsions. Food Chem., 108: 419-424 (2008).

148. Gupta, N.K., Dixit, V.K. Bioavailability enhancement of curcumin by complexation with phosphatidylcholine. J. Pharm. Sci., 100: 1987-1995 (2011).

149. Marczylo, T.H., Verschoyle, R.D., Cooke, D.N., Morazzoni, P., Steward, W.P., Gescher, A.J. Comparison of systemic availability of curcumin with that of curcumin formulated with phosphatidylcholine. Cancer Chemother. Pharmacol., 60: 171-177 (2007).

150. Maiti, K., Mukherjee, K., Gantait, A., Saha, B.P., Mukherjee, P.K. Curcumin-phospholipid complex: Preparation, therapeutic evaluation and pharmacokinetic study in rats. Int. J. Pharm., 330: 155-163 (2007).

151. Sou, K., Inenaga, S., Takeoka, S., Tsuchida, E. Loading of curcumin into macrophages using lipid-based nanoparticles. Int. J. Pharm., 352: 287-293 (2008).

152. Kakkar, V., Singh, S., Singla, D., Kaur, I.P. Exploring solid lipid nanoparticles to enhance the oral bioavailability of curcumin. Mol. Nutr. Food Res., 55: 495-503 (2011).

153. Mulik, R.S., Moenkkoenen, J., Juvonen, R.O., Mahadik, K.R., Paradkar, A.R. Transferrin mediated solid lipid nanoparticles containing curcumin: enhanced in vitro anti-cancer activity by induction of apoptosis. Int. J. Pharm., 398: 190-203 (2010).

154. Tiyaboonchai, W., Tungpradit, W., Plianbangchang, P. Formulation and characterization of curcuminoids loaded solid lipid nanoparticles. Int. J. Pharm., 337: 299-306 (2007).

155. Yadav, V.R., Suresh, S., Devi, K., Yadav, S. Novel formulation of solid lipid microparticles of curcumin for anti-angiogenic and anti-inflammatory activity for optimization of therapy of inflammatory bowel disease. J. Pharm. Pharmacol., 61: 311-321 (2009).

156. di Cagno, M., Styskala, J., Hlaváč, J., Brandl, M., Bauer-Brandl, A., Skalko-Basnet, N. Liposomal solubilization of new 3-hydroxy-quinolinone derivatives with promising anti-cancer activity: A screening method to identify maximum incorporation capacity. J. Liposome Res. 2011, doi:10.3109/08982104.2010.550265.

157. Kunwar, A., Barik, A., Pandey, R., Priyadarsini, I.K. Transport of liposomal and albumin loaded curcumin to living cells: An absorption and fluorescence spectroscopic study. BBA-Gen. Subjects, 1760: 1513-1520 (2006).

158. Chen, C., Johnston, T.D., Jeon, H., Gedaly, R., McHugh, P.P., Burke, T.G., Ranjan, D. An in vitro study of liposomal curcumin: Stability, toxicity and biological activity in human lymphocytes and Epstein-Barr virus-transformed human B-cells. Int. J. Pharma., 366: 133-139 (2009).

159. Li, L., Braiteh, F.S., Kurzrock, R. Liposome-encapsulated curcumin: In vitro and in vivo effects on proliferation, apoptosis, signalling, and angiogenesis. Cancer, 104: 1322-1331 (2005).

160. Li, L., Ahmed, B., Mehta, K., Kurzrock, R. Liposomal curcumin with and without oxaliplatin: Effects on cell growth, apoptosis, and angiogenesis in colorectal cancer. Mol. Cancer Ther., 6: 1276-1282 (2007).

161. Thangapazham, R.L., Puri, A., Tele, S., Blumenthal, R., Maheshwari, R.K. Evaluation of a nanotechnology-based carrier for delivery of curcumin in prostate cancer cells. Int. J. Oncol., 32: 1119-1123 (2008).

162. Wang, D., Veena, M.S., Stevenson, K., Tang, C., Ho, B., Suh, J.D., Duarte, V.M., Faull, K.F., Mehta, K., Srivatsan, E.S., Wang, M.B. Liposome-encapsulated curcumin suppresses growth of head and neck squamous cell carcinoma in vitro and in xenografts through the inhibition of nuclear factor- $\kappa \mathrm{B}$ by an AKT-independent pathway. Clin. Cancer Res., 14: 6228-6236 (2008).

163. Takahashi, M., Inafuku, K., Miyagi, T., Oku, H., Wada, K., Imura, T., Kitamoto, D. Efficient preparation of liposomes encapsulating food materials using lecithins by a mechanochemical method. J. Oleo Sci., 56: 35-42 (2007).

164. Aukunuru, J., Joginapally, S., Gaddam, N., Burra, M., Bonepally, C.R., Prabhakar, K. Preparation, characterization and evaluation of hepatoprotective activity of an intravenous liposomal formulation of bis-demethoxy curcumin analogue (BDMCA). Int. J. Drug Dev. Res., 1: 37-46 (2009). 
165. Narayanan, N.K., Nargi, D., Randolph, C., Narayanan, B.A. Liposome encapsulation of curcumin and resveratrol in combination reduces prostate cancer incidence in PTEN knockout mice. Int. J. Cancer, 125: 1-8 (2009).

166. Mourtas, S., Canovi, M., Zona, C., Aurilia, D., Niarakis, A, La Ferla, B., Salmona, M., Nicotra, F., Gobbi, M., Antimisiaris, S.G. Curcumin-decorated nanoliposomes with very high affinity for amyloid- $\beta_{1}-42$ peptide. Biomaterials, 32: 1635-1645 (2011).

167. Food, Nutrition and the Prevention of Cancer: A Global Prspective, Washington DC, World Cancer Research Fund/American Institute for Cancer Research, 1997.

168. Lachance. P., Langseth, L. The RDA concept: Time for a change? Nutr. Rev., 52: 266-270 (1994).

169. Guenther, P.M., Dodd, K.W., Reedy, J., Krebs-Smith, S.M. Most Americans eat much less than recommended amounts of fruits and vegetables. J. Am. Diet Assoc., 106: 1371-1379 (2006).

170. Conney, A.H. Enzyme induction and dietary chemicals as approaches to cancer chemoprevention: The seventh DeWitt S. Goodman lecture. Cancer Res., 63: 7005-7031 (2003).

171. Oppenheimer, A. Turmeric (curcumin) in biliary diseases. Lancet, 229: 619-621 (1937).

172. Villegas, I., Sanchez-Fidalgo, S., de la Lastra, C.A. New mechanism and therapeutic potential of curcumin for colorectal cancer. Mol. Nutr. Food Res., 52: 1040-1061 (2008).

173. Schmidt, B.M., Ribnicky, D.M., Lipsky, P.E., Raskin, I. Revisiting the ancient concept of botanical therpeutics. Nat. Chem. Biol., 3: 360-366 (2007).

174. Khafif, A., Schantz, S.P., Chou, T.C., Edelstein, D., Sacks, P.G. Quantitation of chemopreventive synergism between (-)-epigallocatechin-3-gallate and curcumin in normal, premalignant and malignant human oral epithelial cells. Carcinogenesis, 19: 419-424 (1998).

175. Verma, S.P., Salamone, E., Goldin, B. Curcumin and genistein, plant natural products, show synergistic inhibitory effects on the growth of human breast cancer MCF-7 cells induced by estrogenic pesticides. Biochem. Biophys. Res. Commun., 233: 692-696 (1997).

176. Du, B., Jiang, L., Xia, Q., Zhong, L. Synergistic inhibitory effects of curcumin and 5-fluorouracil on the growth of the human colon cancer cell line HT-29. Chemother., 52: 23-28 (2006).

177. Sen, S., Sharma, H., Singh, N. Curcumin enhances vinorelbine mediated apoptosis in NSCLC cells by the mitochondrial pathway. Biochem. Biophys. Res. Commun., 331: 1245-1252 (2005). 